SEDIMENTATION AND WATER QUALITY IN THE WEST BRANCH SHADE RIVER BASIN, OHIO, 1983-85

By Carolyn J. Oblinger Childress and Rick L. Jones

U.S. GEOLOGICAL SURVEY

Water-Resources Investigations Report 87-4262

Prepared in cooperation with the OHIO DEPARTMENT OF NATURAL RESOURCES, DIVISION OF RECLAMATION

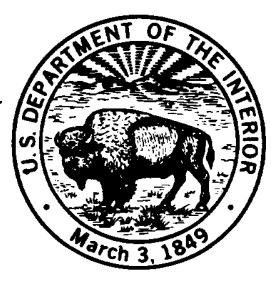

Columbus, Ohio 


\section{DEPARTMENT OF THE INTERIOR \\ DONALD PAUL HODEL, Secretary \\ U.S. GEOLOGICAL SURVEY}

Dallas L. Peck, Director

For additional information write to:

\section{District Chief} Water Resources Division U.S. Geological Survey 975 W. Third Avenue Columbus, OH 43212-3192
Copies of this report can be purchased from:

U.S. Geological Survey Books and Open-File Reports Section Box 25425, Federal Center Denver, CO 80225 


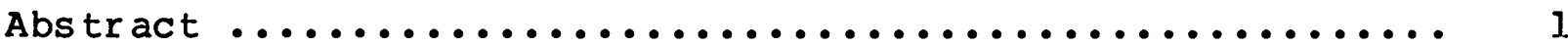

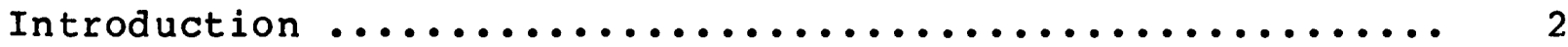

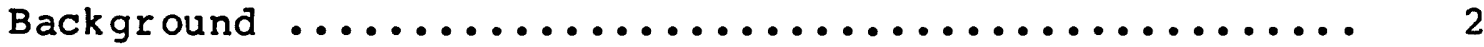

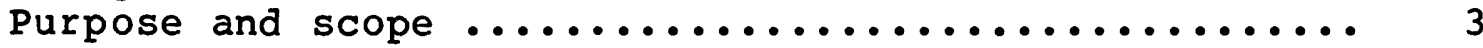

Description of the shade River basin ................ 7

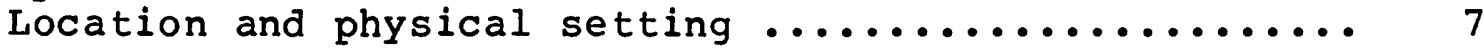

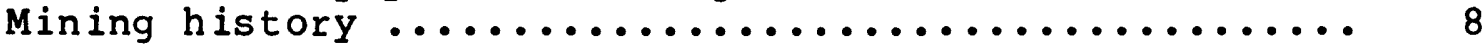

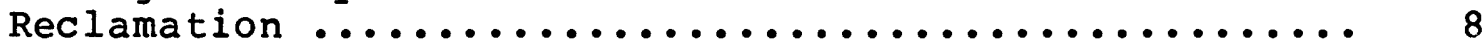

Methods of $s$ tudy ............................... 10

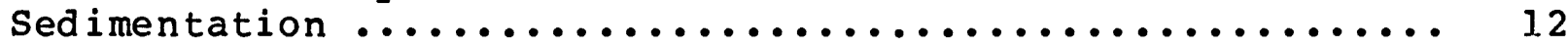

Mean suspended-sediment concentration ............ 13

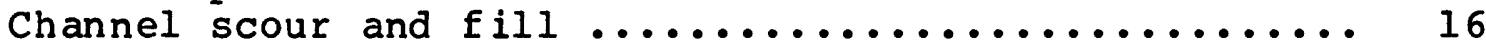

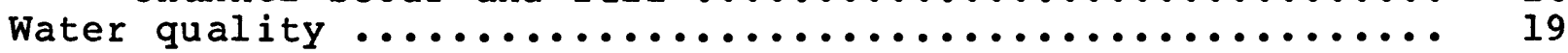

Summary and conclusions........................... 27

Selected references ............................. 28

\section{ILLUSTRATIONS}

Figure 1. Map of the lower reach of an unnamed tributary to the West Branch Shade River near Harisonville showing the active channel

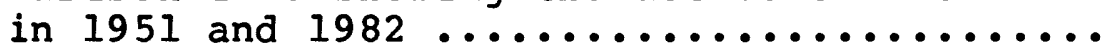

2. Map showing the location of gages, streamchannel cross sections, and water-quality sites in the shade River basin ............

3. Photograph of an old fence line buried by sediment from runoff from an abandoned mine in the West Branch Shade River basin ........

4. Map showing the approximate location of abandoned and reclaimed surface coal mines in the West Branch Shade River basin, October $1984 \ldots \ldots \ldots \ldots \ldots \ldots \ldots \ldots \ldots \ldots \ldots \ldots \ldots . \ldots \ldots$

5-8. Graphs showing the distribution of waterquality data at mined and unmined sites on West and East West Branches of Shade River from samples collected from 1983 through 1986 :

5. Alkalinity concentrations and $\mathrm{pH}$ values ... 20

6. Acidity and sulfate concentrations ....... 21

7. Dissolved-iron and manganese concentrations .................... 22

8. Dissolved-aluminum concentrations and specific-conductance values ........... 


\section{TABLES}

Table 1. Annual total precipitation and departure normal at Carpenter, Ohio, for water

years 1983 through 1985 ...............

2. Total suspended-sediment load, total stream discharge, and mean suspended-sediment concentration for West Branch Shade River near Harrisonville and near Burlingham and East Branch Shade River near Tuppers Plains, ohio .....................

3. Cross-sectional area, normalized area, and positive or negative change in area between measurements from surveys made at 10 locations in the Shade River basin ......

4. Results of water-quality analyses for West Branch Shade River near Harr isonville, at Snowville, and near Burlingham; for the tributary to West Branch Shade River near Burlingham; and for East Branch Shade River near Tuppers Plains, Ohio, from June 1983 through July 1986

5-7. Daily mean streamflow, daily mean suspendedsediment concentration, and daily suspendedsediment discharge during water years 1983 through 1985 :

5. East Branch Shade River near Tuppers

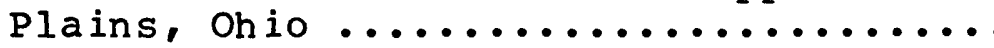

6. West Branch Shade River near Burlingham,

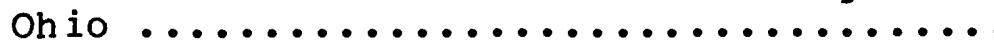

7. West Branch Shade River near Harrisonville,

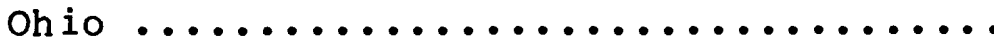


For the convenience of readers who may prefer to use metric (International System) units rather than the inch-pound units used in this report, values may be converted by using the following factors:

Multiply inch-pound unit

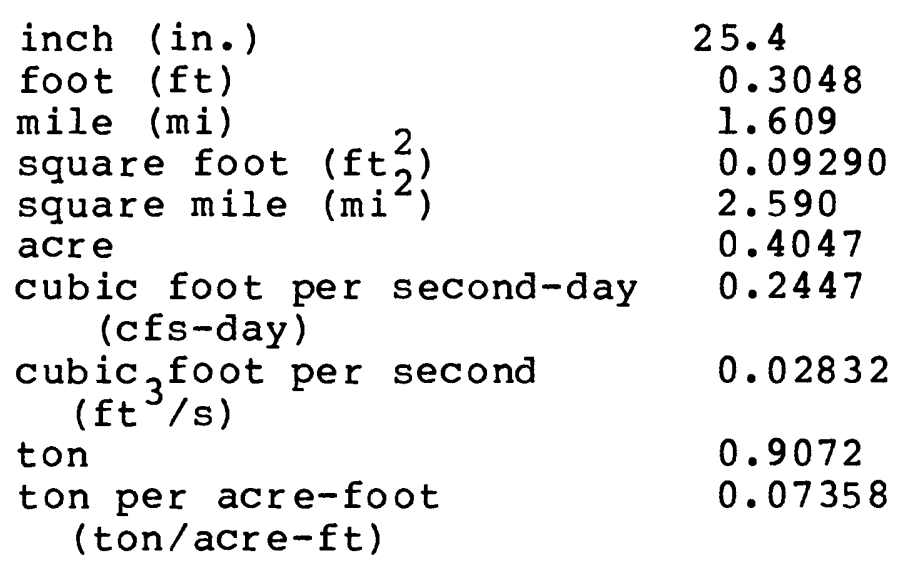

$$
\begin{aligned}
& 25.4 \\
& 0.3048 \\
& 1.609 \\
& 0.09290 \\
& 2.590 \\
& 0.4047 \\
& 0.2447 \\
& 0.02832
\end{aligned}
$$$$
0.9072
$$

0.07358

By

\section{To obtain metric unit}

millimeter (mm)

$$
\text { meter (m) }
$$

kilometer $(\mathrm{km})$ square meter $\left(\mathrm{m}^{2}\right)$ square kilometer $\left(\mathrm{km}^{2}\right)$ square hectometer cubic hectometer $\left(\mathrm{hm}^{3}\right)$

cubic 3 meter per second $(\mathrm{m} / \mathrm{s})$

megagram (Mg)

megagram per cubic hectometer $\left(\mathrm{Mg} / \mathrm{hm}^{3}\right)$

Temperature in degrees Celsius $\left({ }^{\circ} \mathrm{C}\right)$ can be converted to degrees Fahrenheit $\left({ }_{F}\right)$ by the following equation:

$$
F=1.8\left({ }^{\circ} \mathrm{C}\right)+32
$$




\title{
SEDIMENTATION AND WATER QUALITY IN THE WEST BRANCH SHADE RIVER BASIN, OHIO, 1983-85
}

\author{
By C. J. Oblinger Childress and Rick L. Jones
}

\section{ABSTRACT}

Loss of channel conveyance from deposition of sediment from abandoned surface mines in the West $B r a n c h$ Shade River basin has resulted in frequent flooding. In addition, water quality in the West Branch Shade River and some of its tributaries is typical of streams affected by acid mine drainage. About 938 acres were surfaced mined and abandoned in West Branch Shade River basin. By the end of 1984, about 450 acres were reclaimed. The purpose of this study was to measure the effects of abandoned surface mines and their reclamation on suspended-sediment load, channel crosssection profile, and water quality of West Branch Shade River.

Sediment data were collected from June 1983 through September 1985. Daily suspended-sediment samples were collected and continuous streamflow data were recorded at two locations in west Branch Shade River basin and one location in the unmined, East Branch Shade River basin. Water-quality samples were collected three times per year, from June 1983 through July 1986 , at four locations in the West Branch Shade River basin and at one location in East Branch Shade River basin. Stream-channel cross sections were surveyed at least twice per year at 10 locations.

During the period of study, annual mean suspended-sediment concentration was unchanged for the unmined, East Branch Shade River basin; 0.28 ton per acre-foot of runoff in 1984 and 1985 water years. Annual suspended-sediment concentration, in tons per acre foot, in West Branch Shade River near Harrisonville, which was 100 percent reclaimed by the end of 1984 , decreased from 8.6 in 1984 water year to 0.15 in 1985 water year. In West $\mathrm{Branch}$ Shade River near Burlingham, where 48 percent of the abandoned mines were reclaimed by the end of 1984, annual mean suspended-sediment concentration was unchanged $(0.5$ ton per acre-foot of runoff) in 1984 and 1985 water years and was twice that of the unmined basin.

Channel profiles, surveyed at each of the 10 cross sections, indicated scouring at two locations and filling at one location. West Branch Shade River near Harrisonville was scouring, whereas West Branch Shade River near Burlingham was filling. Although the source of sediment in the headwaters has been greatly reduced with reclamation, the sediments previously deposited and stored in the channel of West Branch Shade River most likely will continue to provide a suspended-sediment supply and contribute to channel filling farther downstream. In addition, part of West Branch Shade River basin is still largely unreclaimed and continues as a suspended-sediment source. 
On the basis of successive cross-section profiles, the downstream-most cross section surveyed in Kingsbury Creek, a tributary to West Branch Shade River, also appeared to be scouring. The cause of the scouring is unknown, as no reclamation activities have occurred in that part of the basin.

The quality of West Branch Shade River was characteristic of streams draining abandoned or improperly reclaimed surface mines in southeastern Ohio. Median alkalinity was less than $25 \mathrm{mg} / \mathrm{I}$ (milligrams per liter) as $\mathrm{CaCO}_{3}$ at the three mined sites. Median sulfate concentration was $44 \mathrm{mg} / \mathrm{L}$ at the unmined site compared to $128 \mathrm{mg} / \mathrm{L}$ at the mined sites. Median manganese concentration was 10 times higher at the mined sites than the unmined sites. Both sulfate and manganese are indicators of the presence of acid mine drainage.

The greatest change in water quality during the study period was observed in West Branch Shade River near Harrisonville, above which all abandoned mine lands were reclaimed. The pH at that site increased to neutral by the end of the study. In addition, alkalinity concentration increased, and acidity concentration decreased. As has been observed in previous studies of abandoned surface mines that have been reclaimed, manganese and sulfate concentrations did not change following reclamation. No change in water quality was observed at the two downstream sites during the period of study. However, the percentage of abandoned mined lands that were reclaimed was much smaller above these sites (48 percent).

\section{INTRODUCTION}

\section{Background}

West Branch Shade River basin was surface mined for coal from the mid-1940's through the early 1960's. Although mine operators were required under Ohio law to reclaim surface mines, reclamation, at that time, generally consisted of only regrading and seeding. Mine spoils in this area typically are too acid and too erodible to support new vegetation and the law did not require that spoils be chemically treated to enhance the likelihood of plant survival. Barren slopes with no vegetation for protection against erosion redeveloped in many areas after reclamation. As a result, much of the area in the headwaters of West Branch shade River basin is marked by disturbed land, highwalls, and spoil piles that are devoid of vegetation. Soils from these unvegetated areas are subject to erosion. During periods of storm runoff, soils are transported to the stream channel.

Loss of channel conveyance caused by this deposition of sediment has resulted in frequent flooding. Dredging at bridge crossings has been necessary to reduce flooding of roadways. The filling of West Branch Shade River channel following mining activities is evident from aerial photographs taken in 1951 and in 
1981. Figure 1 shows the channel width of the unnamed tributary to West Branch Shade River as seen from these aerial photographs (the cross-section location shown in $\mathrm{fig}$. 1 corresponds to cross section 3 in fig. 2). In 1951, the active channel was narrow and well defined and riparian land was typically under cultivation. In 1981, nearly 30 years after the most active period of surface mining, the channel had widened considerably. Excessive sediment loads from abandoned mines had been deposited in the river valley and alluvial fans had developed at the mouths of each tributary. Thus, much of the riparian land under cultivation in 1951 had become swamp by 1981 and remains so today. In many areas, the depth of deposited sediments also can be clearly gauged. For example, in a photograph taken downslope from abandoned mines in 1984 (fig. 3) the tops of fence posts are all that remain exposed of a fence line that has been buried by the accumulation of sediment.

In addition to excessive sediment transport and deposition, water quality in West Branch Shade River and some of its tributaries is of concern (Ohio Board of Unreclaimed Strip Mine Lands, 1974). The quality of the headwaters of West Branch Shade River basin generally are degraded, typical of streams affected by acid mine drainage.

In 1978, the U.S. Department of Agriculture, Soil Conservation Service and the Ohio Department of Natural Resources, Division of Reclamation began reclaiming some of these abandoned surface mines with funds made available through the Surface Mining Reclamation and Control Act (PL 95-87). Reclamation is expected to reduce sediment loads from source areas and, ultimately, should increase channel conveyance. In addition, reclamation is expected to result in improved water quality.

A study was begun in 1983 in cooperation with the Ohio Department of Natural Resources, Divison of Reclamation, to measure the effects of reclamation of abandoned surface mines in West Branch Shade River basin on sedimentation and water quality.

\section{Purpose and Scope}

This report presents a summary and analysis of data on suspended-sediment load, channel conveyance, and water quality that were collected between June 1983 and July 1986. Comparisons are made between data from the mined West Branch Shade River basin and the unmined East Branch Shade River basin.

Daily suspended-sediment and streamflow data were collected at three streamflow-gaging stations located on West and East Branches of the Shade River ( $f$ ig. 2). Water-quality data were collected at five locations on West and East Branches of the Shade River, and stream-channel cross-section elevations were surveyed at 10 locations on East and West Branch Shade River and West Branch Shade River tributaries. 


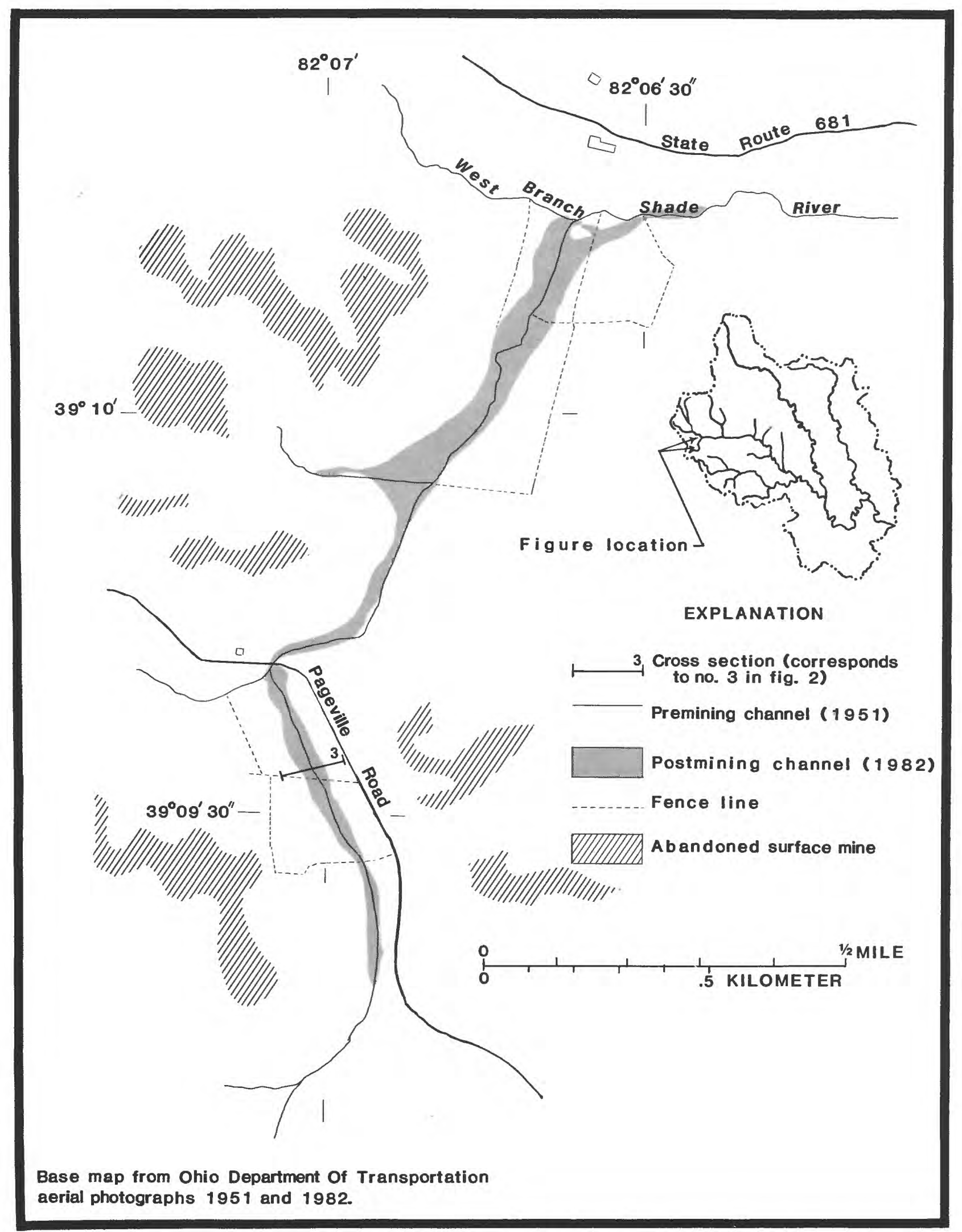

Figure 1.--Lower reach of the unnamed tributary to West Branch Shade River near Harrisonville showing the active channel in 1951 and 1982. 

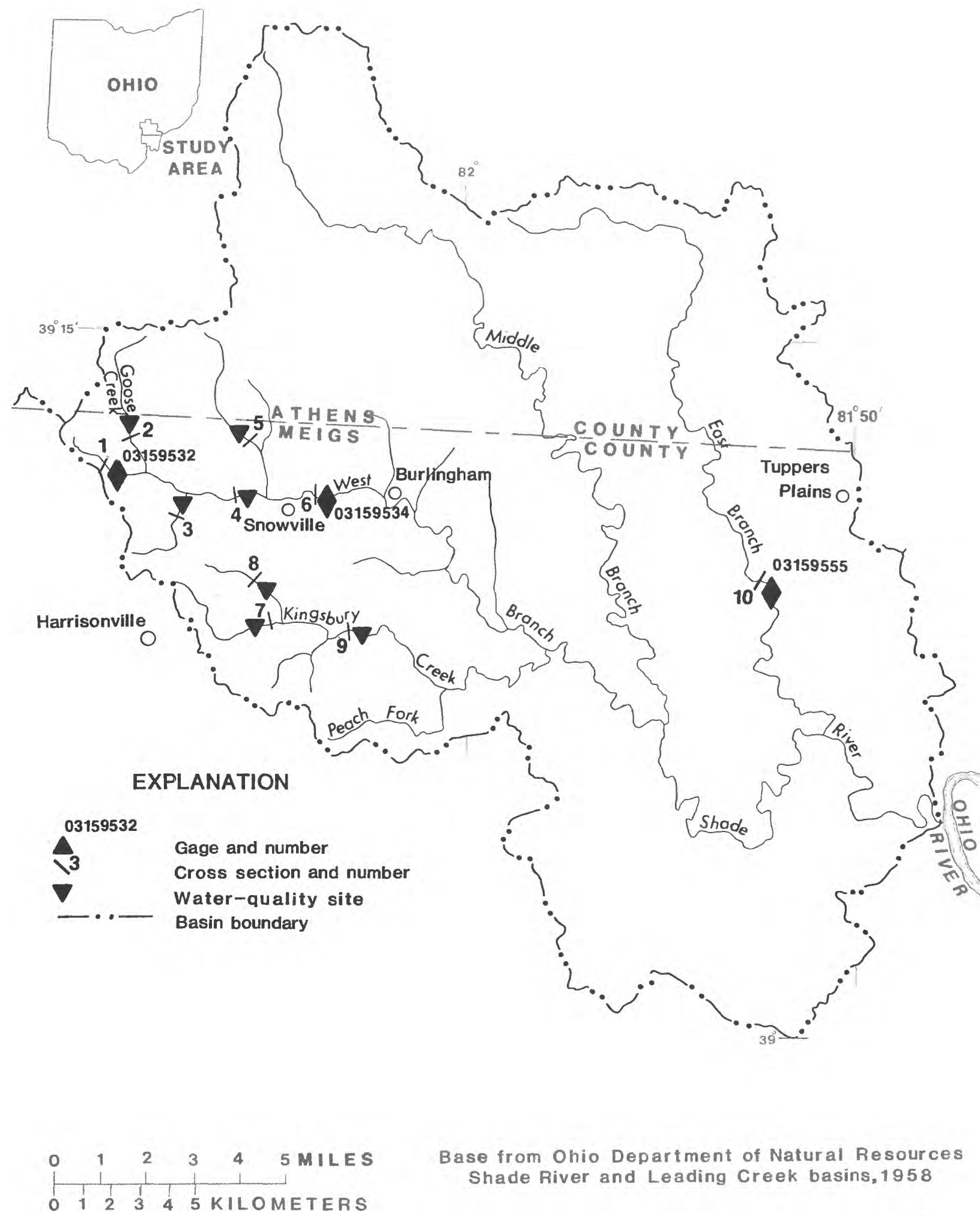

Base from Ohio Department of Natural Resources Shade River and Leading Creek basins, 1958

Figure 2.--Locations of gages, stream-channel cross sections, and water-quality sites in the Shade River basin. 


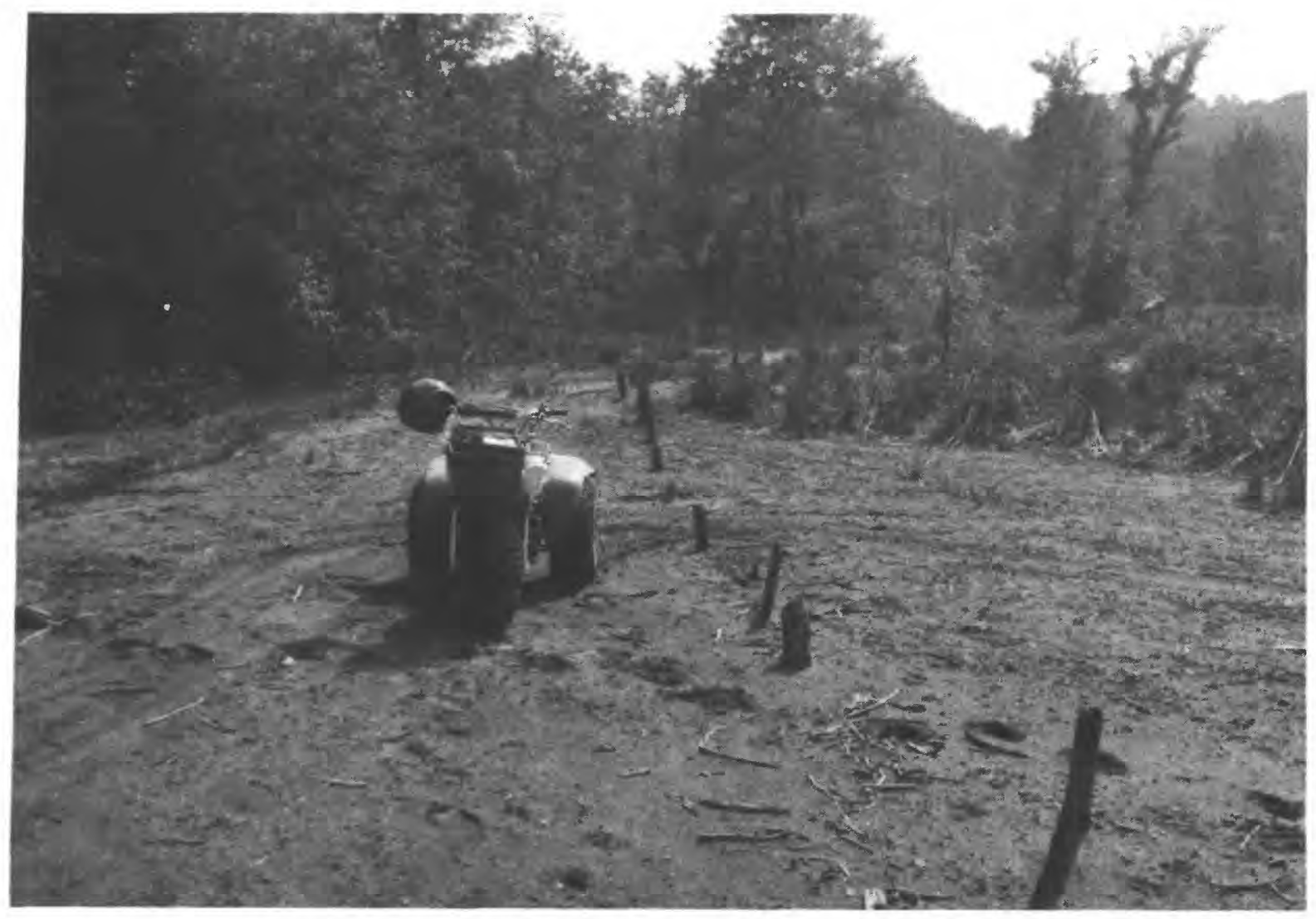

Figure 3.-- An old fence line buried by sediment from runoff from an abandoned surface mine in the West Branch Shade River basin. (View to south) 


\section{DESCRIPTION OF THE SHADE RIVER BASIN \\ Location and Physical setting}

Shade River is a tributary to the Ohio River and drains $221 \mathrm{mi}^{2}$ (square miles), most of which is in eastern and northcentral Meigs County in southeastern Ohjo. There are threg main branches: Wegt (drainage area, $71.3 \mathrm{mi}^{2}$ ), Middle (57.6 $\mathrm{mi}^{2}$ ), and East $\left(54.9 \mathrm{mi}^{2}\right)$.

The Shade River basin is located in the unglaciated Appalachian Plateaus physiographic province, which is characterized by eastward dipping strata dissected by steep, narrow valleys. Rocks of the Conemaugh and Monongahela Formations of Pennsylvanian age crop out in the central and western coal-producing part of Meigs County, and rocks of the Dunkard group of Pennsylvanian and Permian age crop out in the eastern third of the county (Brant and DeLong, 1960). Bedrock is primarily sandstone and shale. Limestone strata are not well developed. The main coal-producing seams are the Lower Kittaning, Upper Freeport, Pittsburgh, Pomeroy, and Meigs Creek.

The mean annual temperature was 53.2 degrees Fahrenheit over an 18-year period at Carpenter, Ohio, located 4 miles westsouthwest of the West Branch Shade River gage near Harrisonville (U.S. Department of Commerce 1982). Annual precipitation has averaged 40.4 inches over the same period (U.S. Department of Commerce, 1983). Annual total precipitation and departure from normal for each year of the study are shown in table 1.

Table 1.--Annual total precipitation and departure from normal at Carpenter, Ohio, for water years 1983 through 1985

water year
Total precipitation, in inches
Departure from the mean for the period, in inches
$1983^{2}$

1984

1985
$3 \frac{15.6}{40.4}$

42.7
$-4.2$

0

$+2.3$

${ }^{1}$ Water year extends from October $I$ of the previous year through September 30 .

2 Total is for the partial water year, from May through september, during which data were collected.

${ }^{3}$ Estimated with record from a nearby station (McArthur, Ohio) for months with missing record. 
The channel of East Branch Shade River is characterized by series of pools and riffles typical of Ohio streams. Streambed material is primarily cobbles and sand. Streamflow at the gage (fig. l) is intermittent during the driest months of the year.

The channel of West Branch Shade River lacks pool-and-riffle sequences and is braided above Snowville (fig. 1). Bed material. is primarily composed of sand and silt. A braided channel can be a response to a sediment load that is too large to be handled by a single channel and often is associated with an aggrading stream (Leopold and others, 1964, p. 294). Flow at the two West Branch Shade River gages is intermittent during all but the wettest months of the year.

\section{Mining History}

Although coal mining was first reported in Meigs County in 1806, the first report of surface mining was not until 1940. Most coal was extracted from the basin through the 1950's and into the $1960^{\prime} \mathrm{s}$. By the mid-1960's, almost all mining activity had ended. Today there are no active surface coal mines in the basin.

About 938 acres have been surface mined in the Shade River basin (U.S. Department of Agriculture, 1985); most were unreclaimed or inadequately reclaimed after mining. Mining was most intense in the upper part of West Branch basin; approximately 19 percent of the drainage area above the West Branch Shade River gage near Harrisonville (station 03159532) and 8 percent of the drainage area above the West Branch Shade River gage near Burlingham (station 03159534) had been surface mined (fig. 4). East Branch Shade River basin was not surface mined and serves as a control site for this study.

\section{Reclamation}

Reclamation of abandoned or unsuccessfully reclaimed mines in West Branch Shade River basin was begun in 1978 by the U.S. Department of Agriculture, Soil Conservation Service, and the Ohio Department of Natural Resources, Division of Reclamation. These agencies had reclaimed approximately 450 acres of abandoned surface mines in the West Branch Shade River basin by the end of 1984 (fig. 4). The reclamation process included regrading the land surface to reduce slopes and provide surface or subsurface drainage, addition of a layer of top soil, incorporation of fertilizer and (or) lime, and finally seeding and mulching. During reclamation, sediment ponds were constructed and used to prevent sediment from reaching the receiving stream.

The Ohio Department of Natural Resources funded reclamation of 100 acres (area A, fig. 4) in 1978, and 235 acres (area B, fig. 4) in the summer of 1984 (M. Farley, Ohio Department of Natural Resources, oral commun., 1984). The U.S. Department of 

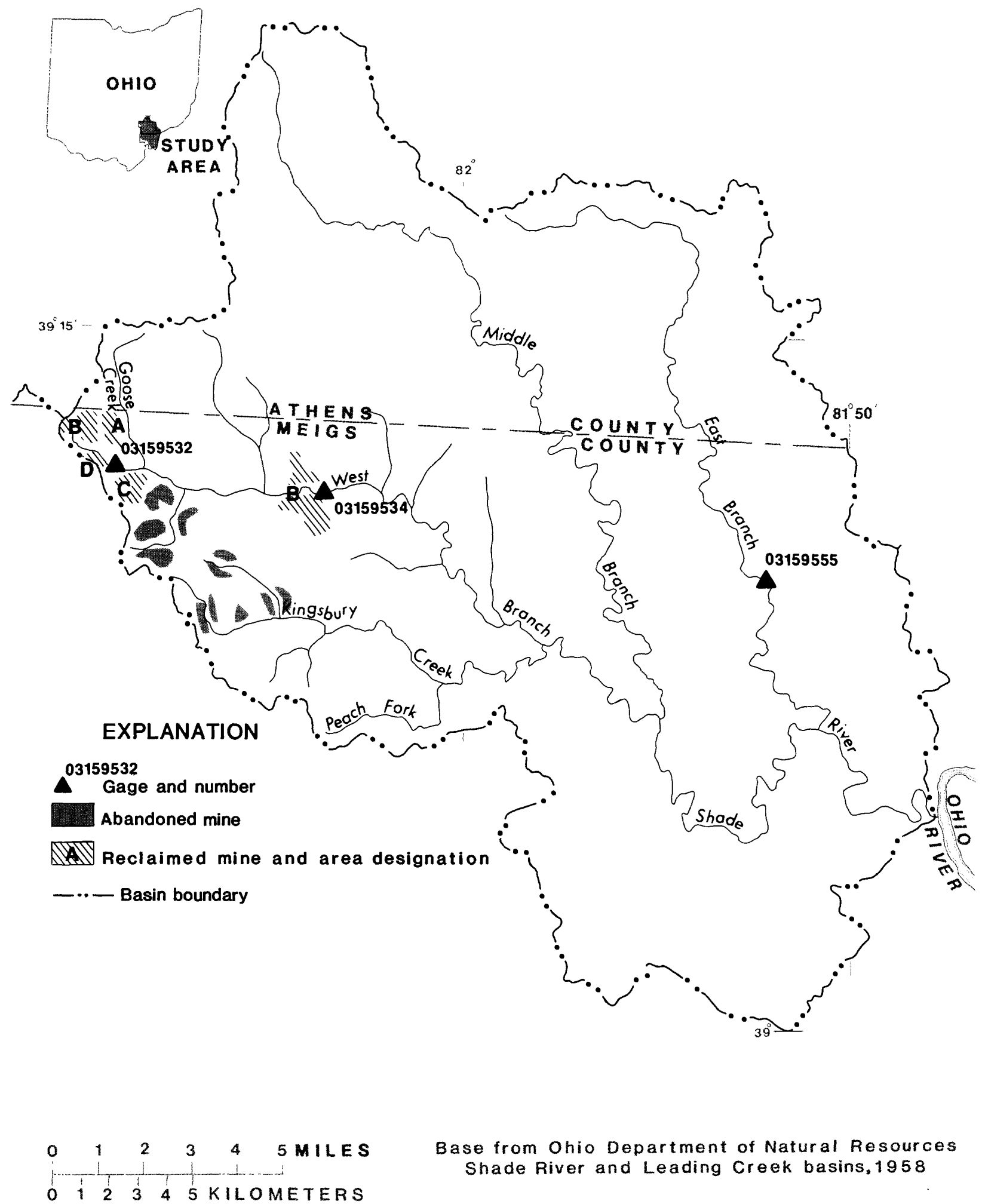
Base from Ohio Department of Natural Resources
Shade River and Leading Creek basins, 1958

Figure 4.--Approximate location of abandoned and reclaimed surface coal mines in the West Branch Shade River basin. October 1984. 
Agriculture, Soil Conservation Service, funded reclamation of about 88 acres (area C, fig. 4) in 1982 and 30 acres (area D, fig. 4) in 1983 (D. Hire, U.S. Department of Agriculture, oral commun., 1984). In all, 188 acres were reclaimed before the beginning of data collection. These areas comprise only 1 percent of the basin above the Burlingham gage.

\section{METHODS OF STUDY}

Three continuous-record streamflow-gaging stations were constructed. Two were located on the West Branch Shade River, near Harrisonville (03159532) and near Burlingham (03159534, fig. 2). The third, on East Branch Shade River near Tuppers Plains (03159555, fig. 2), was a control site. East Branch Shade River basin was selected as a control for this study because of the physiographic, topographic, and lithologic similarity to West $\mathrm{Br}$ anch Shade River basin. (See the section on Location and Physical setting.) With the exception of coal mining (there has been no mining in the East Branch basin), land use also is similar--primarily agriculture, forest, and rural residential.

The West Branch Shade River gaging station near Burlingham and the East Branch Shade River gaging station were equipped with manometers to measure stream stage, U.S. Geological Survey PS-69 automatic sediment samplers, and data loggers to record stage at 15-minute to 1 -hour intervals, depending on flow conditions. The West Branch station near Harrisonville was equipped with a stilling well and float to measure stage, an automatic sampler, and a digital recorder to record stage at 5-minute intervals. Data collection began in June 1983.

Suspended-sediment samples, collected manually using the equal-transit-rate method (U.S. Geological Survey, 1977), were used to establish sediment concentration during base-flow periods.

Suspended-sediment samples were collected during periods of runoff by the automatic samplers. At the stations on East Branch Shade River and West Branch Shade River near Burlingham, the automatic sampler was activated when the stage rose above pre-set thresholds of 7.0 and 3.5 feet, respectively. When the automatic sampler was activated, samples were collected at 15-minute intervals or when a change in stage of 0.5 foot or more occurred. At the station on West Branch Shade River near Harrisonville, the sampler was activated when the stage rose 0.5 foot above base-flow stage. Samples were collected at 5-minute intervals until the stage dropped below the level at which the sampler was activated.

The automatic suspended-sediment sampler withdrew a water sample from a fixed point in the cross section; thus, the point concentration needed to be adjusted to the average suspendedsediment concentration for the cross section. This cross-section average was determined empirically by collecting a manual sample simultaneously with a sample collected by the automatic sampler. 
The manual sample was collected using an integrating method that yields a sample that represents the average suspended-sediment concentration within the cross section. The relation between point sample and integrated sample was used to calculate a correction coefficient. This coefficient was used to adjust pointsample concentration to the average concentration in the cross section (Porterfield, 1972, p. 12). For East Branch Shade River near Tuppers Plains, the coefficient was 1.0. For West Branch Shade River near Burlingham, the coefficient was 0.84 . For West Branch Shade River near Harrisonville, the coefficient was 1.0 .

Sediment samples were analyzed at the U.S. Geological Survey District office in Columbus, Ohio, from May through September 1983 using a method for suspended sediment (Guy, 1969). Heidelberg College Water Quality Laboratory in Tiffin, Ohio, analyzed samples thereafter. The Heidelberg College Laboratory used a method for suspended solids (American Public Health Association and others, 1975) for analyses of samples. To compare the equivalency of the two methods for analysis of sediments in the shade River, duplicate suspended-sediment samples were collected. One duplicate was analyzed in Heidelberg College Laboratory using the suspendedsolids method and the other was analyzed in the U.S. Geological Survey Ohio District office using the suspended-sediment method. Results indicate that there was no significant difference in concentration because of analytical method for suspended-sediment samples from West Branch Shade River.

Daily suspended-sediment load was calculated using one of several methods depending on the completeness of data. For East Branch Shade River near Tuppers Plains, data collection was uncomplicated because of a relatively stable streambed and fairly continuous streamflow. As a result, few data were missing and daily suspended-sediment load was calculated from measured concentrations of suspended sediment and measured streamflow. For days with suspended-sediment concentration missing, loads were estimated from suspended-sediment concentration for comparable streamflow conditions (Porterfield, 1972, p. 20). For West Branch Shade River near Burlingham, record was less complete because the equipment used to measure stage was not sensitive to discontinuous or low streamflow. In addition, extreme shifts in the streambed generally caused the equipment to fail. For days when suspendedsediment concentration was missing, the concentration was assumed to be the same as the suspended-sediment concentration measured under the most recent similar streamflow and antecedent-weather conditions (Porterfield, 1972, p. 20). For days with missing stage record, daily streamflow was determined from record of rainfall and stage on days preceding and following the missing record or was estimated from a nearby gage.

For West Branch Shade River near Harrisonville, data were the least complete because of the same equipment and stream conditions described for the Burlingham gage. For days with missing stage record, streamflow was determined as described above. Further- 
more, because of the small drainage-basin size, it was very difficult to reach the site and collect a suspended-sediment sample in the short time between initial rainfall and peak runoff. As a result, daily suspended-sediment loads were calculated from suspended-sediment rating curves. Instantaneous streamflow data, in cubic feet per second, were related to the corresponding instantaneous suspended-sediment discharge, in tons per day, on logarithmic graph paper. S-shaped curves were manually $f$ it to the data (Colby, 1956). Four suspended-sediment rating curves were developed, each describing a different time period and representing a change in the relation between streamflow and suspendedsediment. These ratings were used with record of daily streamflow to calculate daily suspended-sediment loads.

Stream cross sections were surveyed at nine locations in West Branch Shade River basin and one location in East Branch Shade River basin (fig. 2). The cross sections were surveyed quarterly from July 1983 until september 1984 and twice a year thereafter. Elevations at each point in the cross section were measured relative to an arbitrary datum of 50 feet established on the left bank of each cross section. Elevations were recorded to the nearest 0.1 foot. At least two reference points also were established at each cross section and measured with each survey to cross check the accuracy of the primary reference mark.

Water-quality samples were collected at each of the three gaging stations and at two other locations in West Branch Shade River basin ( $f i g .2$ ) in the winter, spring, and early summer during the study period. Samples were analyzed by U.S. Geological Survey Central Laboratory for concentrations of total and dissolved aluminum, iron, and manganese, and dissolved sulfate using methods described in skougstad and others (19.79). Water discharge, pH, water temperature, and concentrations of alkalinity and acidity were determined on site at the time of sample collection. Alkalinity concentration was determined as described in Skougstad and others (1979, p. 517). Acidity concentration was determined as described in American Public Health Association and others $(1975, \mathrm{p} .275)$.

\section{SEDIMENTATION}

During surface mining, overburden that is removed to expose the coal-bearing strata is accumulated in spoil piles. Spoil piles typically have steep slopes and are lacking topsoil to help support vegetation. As a result, erosion rates from these areas are higher than for any other land use in Ohio (U.S. Department of Agriculture, 1985). The U.S. Department of Agriculture (1985) measured soil-loss rates in excess of 200 tons per acre per year from spoil piles in Meigs County. Most material eroded from the land surface is deposited downslope or in the channel of the receiving water; however, only about 5 to 10 percent is exported from the basin by receiving waters (Trimble, 1975). 
When the suspended-sediment load exceeds the transport capacity of stream-water discharge, the channel typically begins to fill with sediment (Foster and Meyer, 1977). The West Branch Shade River basin is typical of much of southeastern Ohio, where surface mining usually occurs on hillsides and transport capacity decreases as runoff from hillsides reaches the receiving stream in the flat, valley area. Under these conditions, deposited material may form alluvial fans at the confluence of receiving streams and tributaries. Subsequent backfilling of the tributary and main channels further reduces channel capacity and may result in more frequent out-of-bank flooding. These channel overflows may, in turn, lead to deposition of suspended sediment in the flood plain adjacent to the filled channel (Happ and others, 1940, p. 71) and to the formation of elevated natural levees.

However, when suspended-sediment loading decreases so that the stream has the capacity to carry a greater quantity of suspended sediment than is received by the stream from runoff, scouring of the stream channel will occur. This has often been observed below newly built reservoirs because the reservoir acts as a sediment trap. The clear water released below the reservoir in place of the once sediment-laden water causes the channel to scour. Eventually, scouring causes the slope of the streambed to flatten so that the sediment-carrying capacity decreases and a new equilibrium is achieved (Leopold and others, 1964, p. 454-5). A significant reduction in suspended-sediment loading resulting from abandoned surface mine reclamation would be expected to have the same effect on the receiving stream channel.

\section{Mean Suspended-Sediment Concentration}

Mean suspended-sediment concentrations were used to assess whether reclamation in the West Branch Shade River basin was resulting in a decrease in the quantity of suspended sediment carried by the West Branch Shade River. Mean suspended-sediment concentration for a specific period was calculated from total suspended-sediment load and total streamflow for that period. Sediment load is, in part, a function of total annual runoff; thus, total annual load varies due to natural annual variation in rainfall and runoff at each site and varies from site to site due to differences in drainage basin size. Suspended sediment is expressed in this report as total mean concentration, in tons per acre-foot of runoff, in an effort to account for these variations. These data are shown in table 2 for the 1983 through 1985 water years. Because data collection began in the summer of 1983, only 4 months of data were collected in the 1983 water year. Data for the same 4-month period in the 1984 and 1985 water years are presented so that the 1983 partial year may be compared to the same period in following years. 


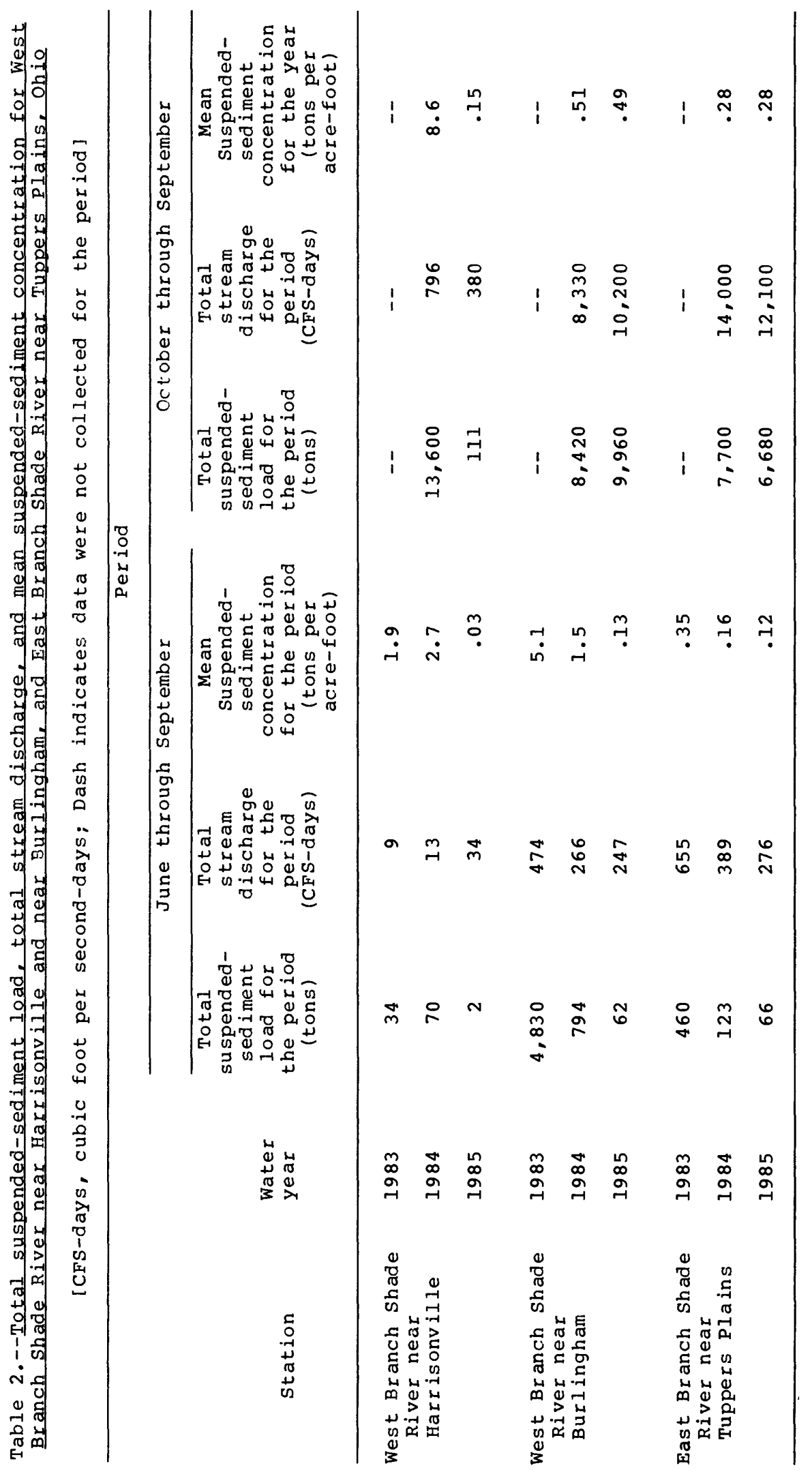


East Branch Shade River basin above the sampling location is unmined and no major land-use changes occurred during the study period. Mean suspended-sediment concentration at East Branch Shade River was 0.28 ton per acre-foot of runoff per year during 1984 and 1985 water years (table 2). More than 70 percent of the annual-suspended-sediment load was transported from February through May (table 5, at back of report).

Mean suspended-sediment concentration for the period June through September for the East Branch site was 0.35 ton per acrefoot of runoff in 1983, 0.16 in 1984, and 0.12 in 1985. However, less than about 2 percent of the total annual suspended-sediment load was transported from June through September (table 5). The relatively high concentration for the period in 1983 compared with the same period for 1984 and 1985 is due to one storm that occurred in July 1983, runoff from which transported 364 tons of suspended sediment or 79 percent of the load measured in the 1983 water year (table 5). In ohio, summer thunderstorms are common, and a single thunderstorm with high rainfall intensity can produce high suspended-sediment concentrations in runoff.

Mean suspended-sediment concentration in West Branch Shade River near Burlingham was about 0.5 ton per acre-foot of runoff during 1984 and 1985 water years (table 2)--nearly twice that for East Branch Shade River basin. No decrease in mean concentration was observed following reclamation of 46 percent of the abandoned-mine lands in 1983 and 1984. The seasonal distribution of suspended-sediment transport was similar to East Branch; more than 60 percent of the annual load was transported from February through May and less than 9 percent was transported from June through September (table 6, at back of report).

Mean suspended-sediment concentration for the period June through September at the Burlingham site, in tons per acre foot of runoff, was 5.1 in 1983, 1.5 in 1984, and 0.13 in 1985. The extremely high suspended-sediment load in June and July of 1983 (table 6) may be due to a combination of factors--erosion from unreclaimed surface mines just upstream from the site and greater total streamflow for the period June through september compared with the same period in 1984 and 1985. In the summer of 1983, none of the abandoned-mine lands immediately upstream of this site had been reclaimed (area B, fig. 4). Reclamation activities began in this area in March 1984 and ended in October 1984.

Mean suspended-sediment concentration for the headwaters of West Branch Shade River near Harrisonville was 8.6 and 0.15 tons per acre-foot of runoff in the 1984 and 1985 water years, respectively (table 2). The pronounced decrease in mean suspendedsediment concentration corresponds to completion of reclamation activities. By the autumn of 1984 , 100 percent of the abandonedmine lands above this site had been reclaimed. Construction of a retention pond (area B, fig. 4) in part accounts for the extremely low annual mean suspended-sediment concentration in 1985. More than 50 percent of the annual load was transported in February through May and less than 2 percent from June through september (table 7, at back of report). 
Mean suspended-sediment concentration, in tons per acrefoot of runoff, for the period June through september for the Harrisonville site was 1.9 in $1983,2.7$ in 1984 , and 0.03 in 1985 (table 2). Reclamation activities were ongoing during the summers of 1983 and 1984. In a 1-week period in March, during which access roads and retention ponds were constructed as the initial phase of reclamation, 5,810 tons of suspended-sediment (41 percent of the annual suspended-sediment load) was transported past the Harrisonville gage in runoff from two storms (table 7). By October 1984, all abandoned surface mines above the Harrisonville gage had been reclaimed.

Channel Scour and Fill

Successive surveys of cross-section profile were used to assess channel scour or fill following reclamation. The following data were calculated from these surveys (table 3): Crosssection area, normalized cross-section area, whether the difference between successive measurements was positive or negative, and the average difference in normalized area between measurements. Normalized area was calculated by dividing each crosssection area by the initial cross-section area. Thus, each area was expressed as a proportion of the initial cross-section area and comparison could be made between streams of differing total area.

No long-term net fill or scour of the stream channel is expected under conditions of equilibrium, although some short-term variation in channel configuration is typical. A long-term net scour or long-term net fill of the channel may indicate a change in the sediment-carrying capacity of the stream (that is, a change in channel conveyance). A positive change in area indicates channel scour, whereas a negative change in area indicates filling of the channel.

For the two cross sections measured in areas with no abandoned surface mines, East Branch Shade River (site 10) and tributary to West Branch Shade River (site 5), cross-section area fluctuated so that the number of times the channel was observed to have filled (that is, there was a negative difference in area between measurements) approximately equalled the number of times the channel was observed to have scoured (table 3). Furthermore, the average change in normalized area was small, -0.1 and 0 , respectively.

Five of the cross sections measured in areas with abandoned surface mines also appeared to be in equilibrium--two sites in the headwaters of Kingsbury Creek (sites 7 and 8); Goose Creek (site 2); a tributary to West Branch Shade River (site 3); and West Branch Shade River at Snowville (site 4). Like the cross sections in the two unmined basins, the cross-section area at these five sites flucuated, and average change in normalized areas was near zero. 


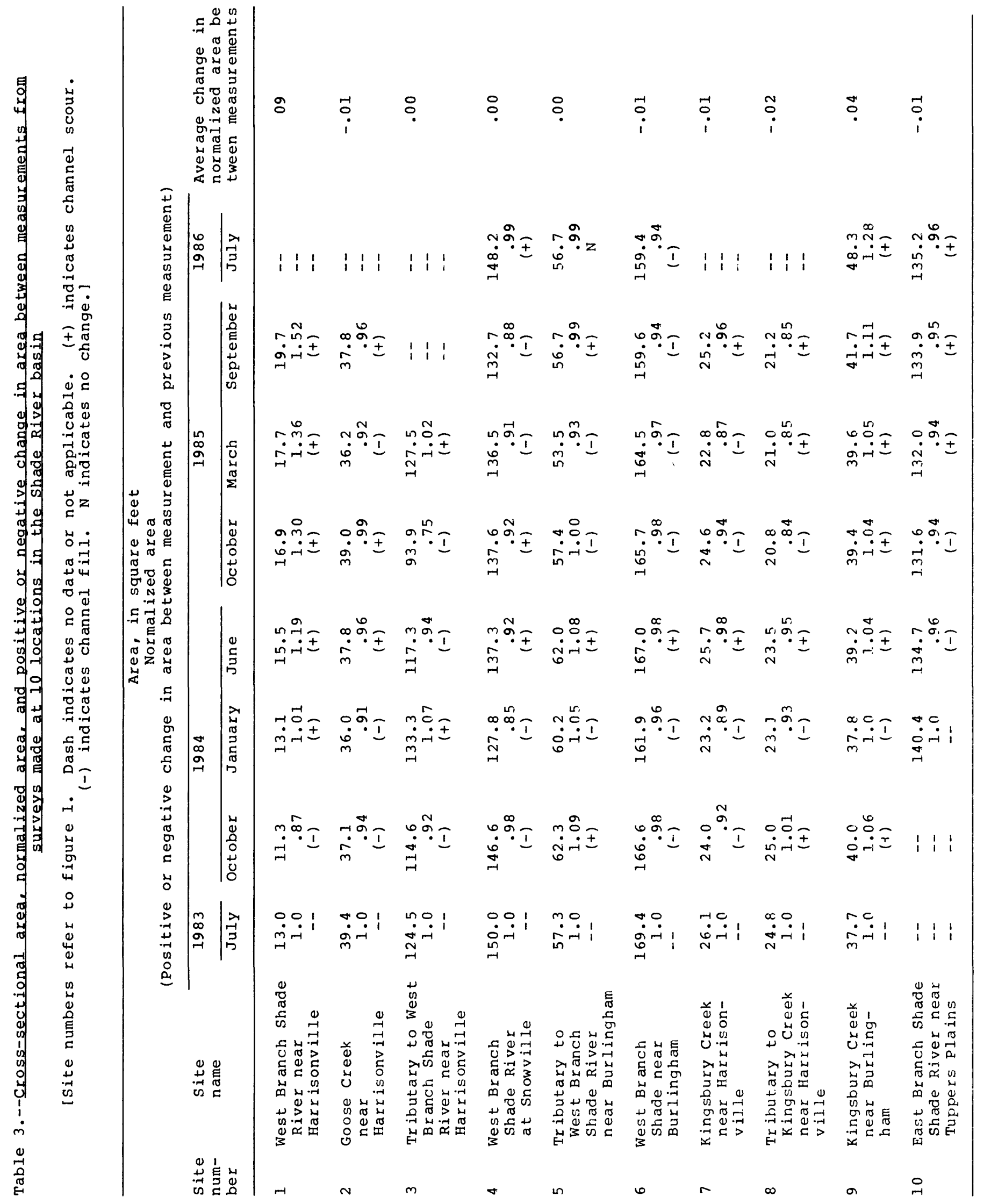


Three sites do not appear to be in equilibrium: West Branch Shade River near Harrisonville and near Burlingham and Kingsbury Creek near Burlingham. Scour of the channel of West Branch Shade River near Harrisonville is evident from consistent positive change between successive measurement of cross-section area (table 3), from the relatively large average change in normalized area, and from visual observations of the streambed. Each successive measurement after the first period of reclamation in 1983 indicated scour. In addition, over the course of the study, the water intake for the streamflow gage needed to be lowered repeatedly because of a drop in the streambed elevation. The change in composition of the bed material also provides evidence that the bed was scouring. By the end of the study period, streambed materials had changed from predominantly sands and silts to predominantly sands and gravels. This change in composition of the bed material was visible from the headwaters to the confluence with Goose Creek. Below the confluence with Goose Creek, the West Branch Shade River widens considerably and the active channel is poorly defined. Much of the river valley from this point to the confluence with the next major tributary is swampland, which acts as a sediment trap.

The channel of West Branch Shade River near Burlingham appears to be filling, based on change in area between measurements. Except for one period, between January and June 1984, cross-section area decreased (negative change in area) with each successive measurement (table 3 ). This indicates that the channel was filling even after reclamation, in 1984, of about 168 acre of abandoned-mine lands immediately upstream of the cross section. Indeed, this is supported by the computed annual suspendedsediment loads; loads did not decrease during the study. However, the magnitude of $f i l l$ was small; average change in cross section area was only -0.1 , the same as at the control site. More data are needed to confirm if the channel will continue to fill.

Although the source of sediment near the headwaters has been greatly reduced because of reclamation of abandoned-mine lands, sediment previously deposited and stored in the channel of the West Branch Shade River most likely continues to provide a supply of suspended sediment (Foster and Meyer, 1977). In addition, unreclaimed mines in the basin ( $f$ ig. 4 ) continue to provide a source of suspended sediment. These two factors, no doubt, account for the continuing high suspended-sediment load near Burlingham and to possible channel filling.

Although bed elevations in the headwaters of Kingsbury Creek appeared to be in equilibrium, a cross section (site 9, fig. 2) in the lower part of the basin appeared to be scouring. No reclamation activities have occurred in the Kingsbury Creek basin to reduce suspended-sediment load, and the reason for the scouring is unknown. 
Weathering and oxidation of pyrite, which is found in bedrock in southeastern Ohio, produces acidity and sulfate. This weathering process is intensified as a result of surface coal mining because of the increased surface area of bedrock exposed when coal is extracted. Furthermore, streams draining abandoned surface mines in areas where local bedrock is composed of few limestonebearing members have relatively low buffering capacity (that is, contain low concentrations of alkalinity); therefore, pH typically is well below neutral. Streams with low pH and high acidity concentrations also typically have high concentrations of dissolved metals as a result of dissolution of minerals in soils and bedrock. These metals remain in solution in accordance with the pH-solubility relationship for each metal.

Streams draining unmined basins in southeastern Ohio typically have relatively high alkalinity and low acidity concentration, near-neutral pH values, and relatively low concentrations of dissolved metals compared with streams draining abandoned-mine lands (Childress, 1984). Comparison of selected chemical constituents in the mined area of West Branch shade River basin with unmined areas illustrates the significant effect that abandoned mines can have on the water quality of the receiving stream.

$\mathrm{pH}$ is a measure of the hydrogen-ion concentration expressed as a negative logarithm to base 10. Medians of $\mathrm{pH}$ at the mined sites were less than neutral (7.0), whereas medians of $\mathrm{pH}$ were greater than neutral at the unmined sites (fig. 5). Alkalinity concentration is a measure of the capacity of stream water to neutralize acids. Median alkalinity concentration for the unnamed tributary to West Branch Shade River near Burlingham that drains an unmined area of the basin was $67 \mathrm{mg} / \mathrm{L}$ (milligrams per liter) as $\mathrm{CaCO}_{3}$ (fig. 5). The median concentration for the East Branch, which drains the more calcareous bedrock formations in the eastern part of the county and which also is unmined, was $120 \mathrm{mg} / \mathrm{L}$. In contrast, median alkalinity concentrations were less than $25 \mathrm{mg} / \mathrm{L}$ at the mined sites (fig. 5). Acidity concentration is a measure of the capacity of the stream water to react with hydroxyl ions. For streams with $\mathrm{pH}$ above 7.0 , acidity was assumed to be equal to zero and therefore was not measured. Concentrations of acidity were assumed to be $0 \mathrm{mg} / \mathrm{L}$ at the two unmined sites based on $\mathrm{pH}$. Median concentrations at the mined sites ranged from 5 to $50 \mathrm{mg} / \mathrm{L}$ (fig. 6).

Median sulfate concentrations were 3 times higher at the mined sites than at the unmined sites (fig. 6). Median dissolvedmanganese concentrations were at least an order of magnitude higher at mined sites than at unmined sites (fig. 7). Both dissolved sulfate and dissolved manganese concentrations were highest in the headwaters of West Branch Shade River where a greater proportion of the basin was mined. Dissolved-iron concentrations fluctuated seasonally, but median concentrations generally were also higher at the mined sites (fig. 7). 

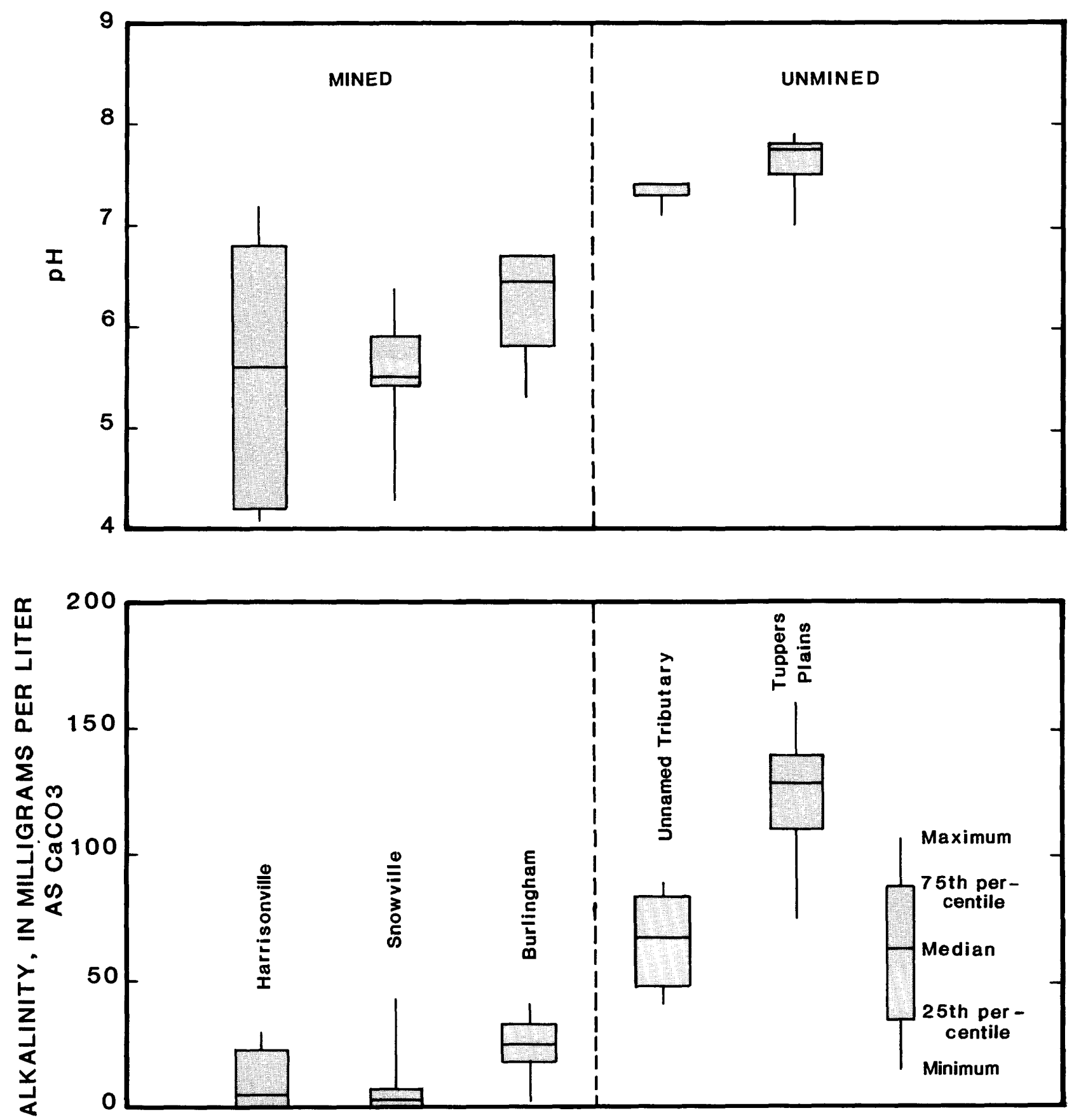

Figure 5.--Distribution of $\mathrm{pH}$ values and alkalinity concentrations at mined and unmined sites on West and East Branches of Shade River from samples collected from 1983 through 1986. 

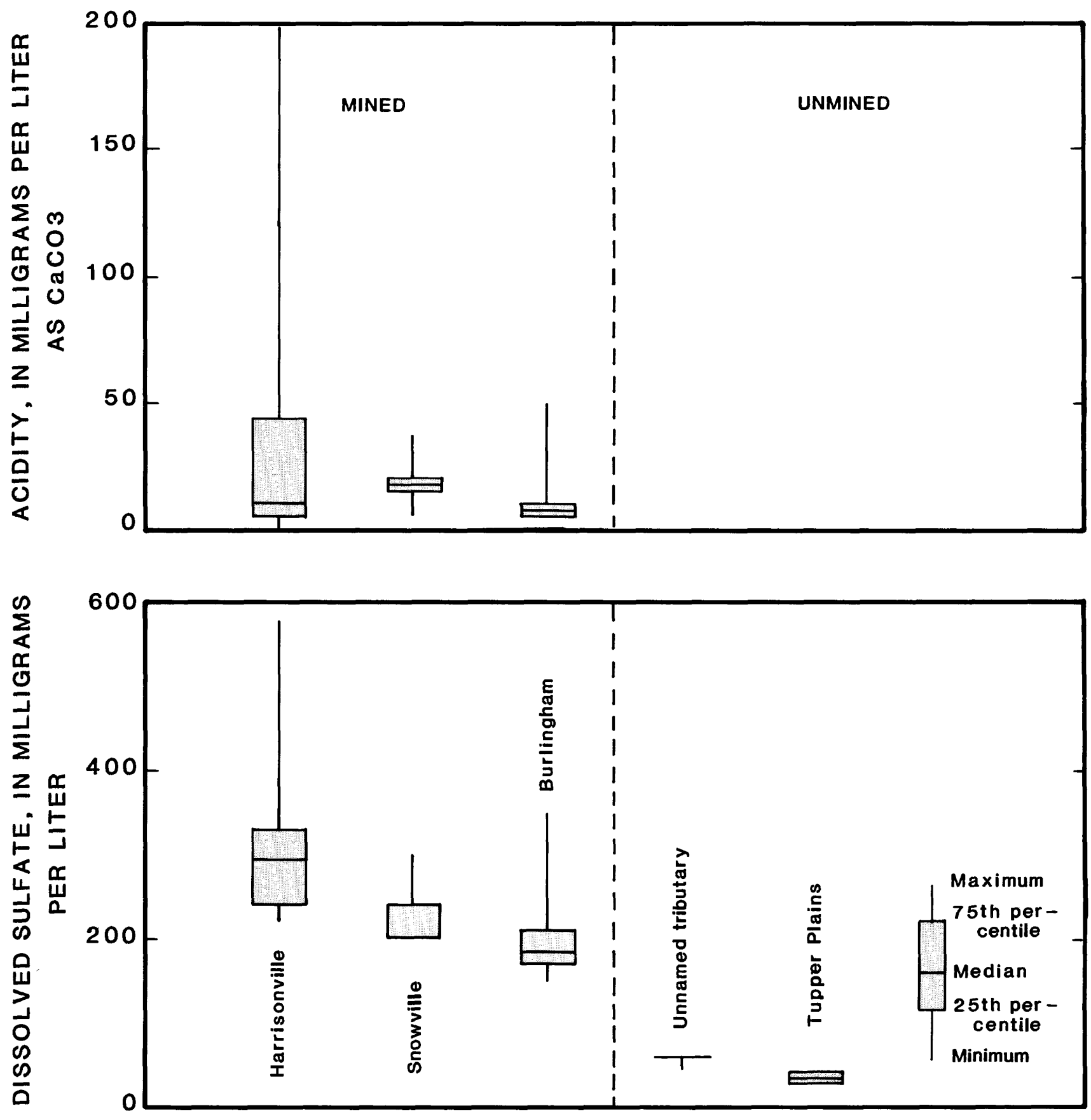

Figure 6.-Distribution of acidity and sulfate concentrations at mined and unmined sites on West and East Branches of Shade River from samples collected from 1983 through 1986. 

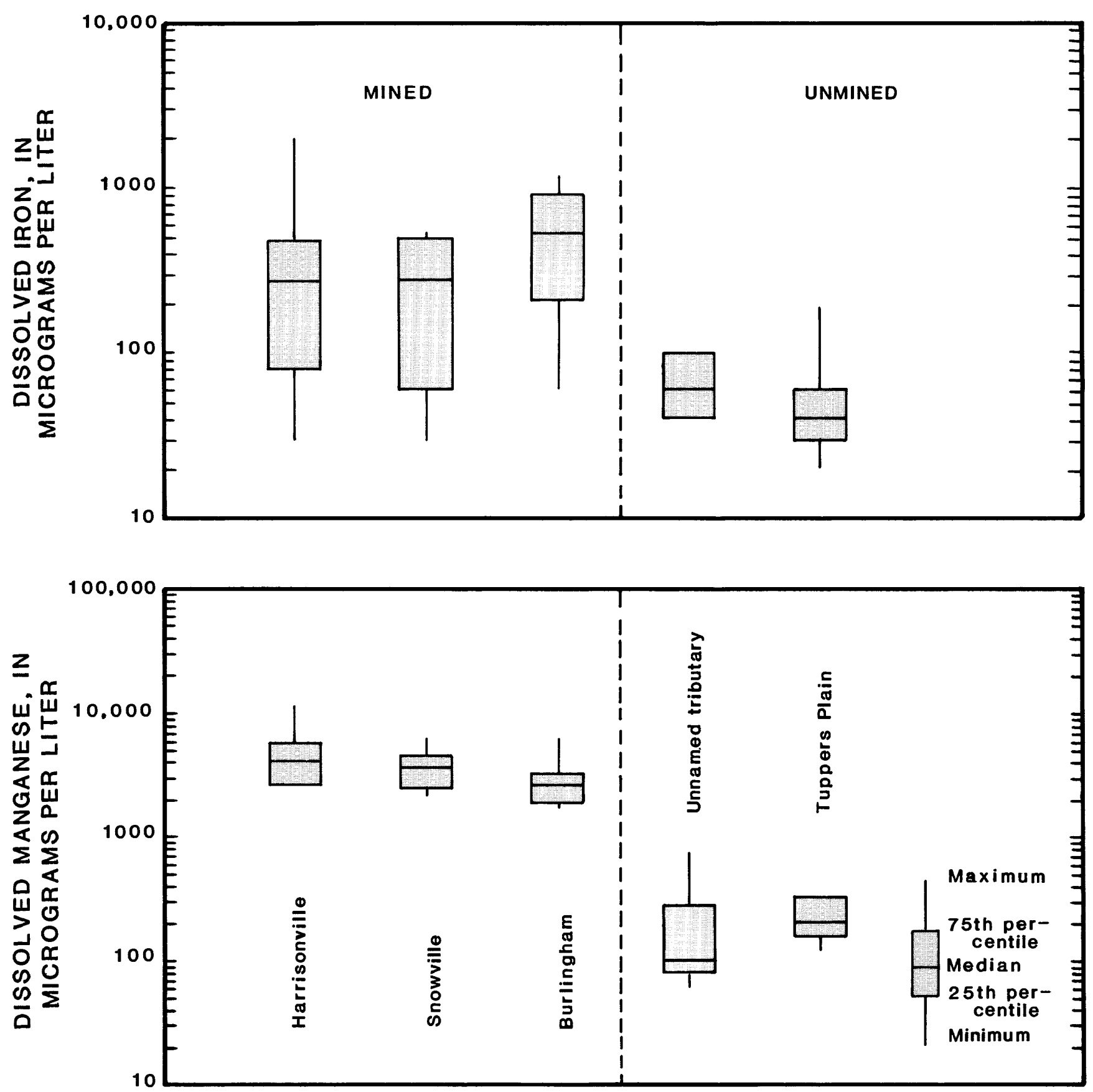

Figure 7.-Distribution of dissolved -iron and -manganese concentrations at mined and unmined sites on West and East Branches of Shade River from samples collected from 1983 through 1986. 
Dissolved-aluminum concentration is related to $\mathrm{pH}$ and is rarely found in natural waters at concentrations above 100-200 ug/L, except in waters of very low pH (Hem, 1985, p. 73). Median dissolved-aluminum concentrations were near $900 \mathrm{ug} / \mathrm{L}$ at the two upstream stations on West $\mathrm{Branch}$ Shade River and less than $200 \mathrm{ug} / \mathrm{L}$ at the unmined sites (fig. 8). Specific conductance is a general indicator of the concentration of dissolved minerals. Median values were highest progressing upstream in West $\mathrm{Br}$ anch Shade River basin and lowest in the streams draining unmined areas (fig. 8).

The period over which data were collected was insufficient to perform valid statistical tests of water-quality trends. The Seasonal Kendall test (Hirsch and others, 1982) is most suitable for application to water-quality data that are typically not normally distributed and that vary seasonally. However, because the period of study was relatively short, there were, at most, two samples per season for trend analysis. Additional data are needed over several more years to test whether there are statistically significant trends in water-quality constituents at any of the sites.

However, changes in concentrations and values of constituents analyzed during the study period suggest that some water-quality improvements are occurring at some sites. All water samples were collected during periods of base flow when drainage from the abandoned mines was not diluted with surface runoff.

Alkalinity concentrations appear to have increased at the West Branch Shade River near Harrisonville, where all abandoned surface mines have been reclaimed. Alkalinity was $0 \mathrm{mg} / \mathrm{L}$ in 1983 and $30 \mathrm{mg} / \mathrm{L}$ in 1986 at approximately the same streamflow. Despite that increase, the alkalinity concentration in 1986 was still less than the concentrations at either unmined site (table 4). Likewise, pH, which in 1983 was lower in the headwaters than anywhere else in the basin, was neutral when measured in 1986. The fact that $\mathrm{pH}$ is neutral, yet alkalinity concentration is lower than found in unmined areas of the West shade River basin, may indicate that there is some continuing acid production but that it is buffered. In contrast, there was no apparent change in alkalinity or $\mathrm{pH}$ at Snowville or Burlingham during the study period (table 4 ).

Dissolved-manganese concentration decreased from 1983 to 1986 at the Harrisonville site. At the sites near Burlingham and Snowville, the concentrations did not change appreciably. The concentration of dissolved manganese at all three mined sites remained well above the concentrations at the two unmined sites (table 4). Dissolved-sulfate concentration did not change appreciably at any of the mined sites and the concentrations remained well above the concentrations at the two unmined sites (table 4 ). 

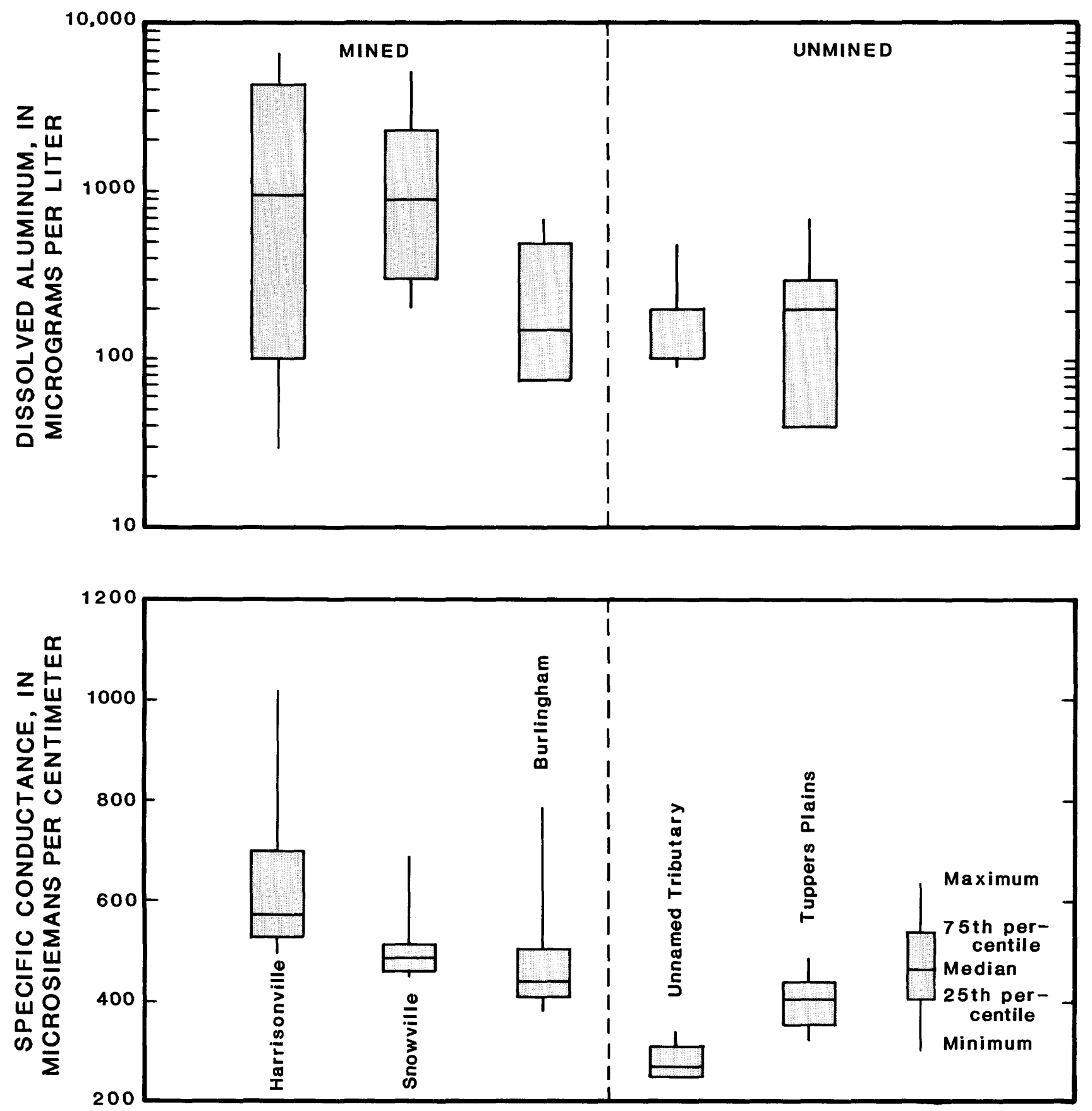

Figure 8.--Distribution of dissolved-aluminium concentrations and specfic conductance values at mined and unmined sites on West and East Branches of Shade River from samples collected from 1983 through 1986. 


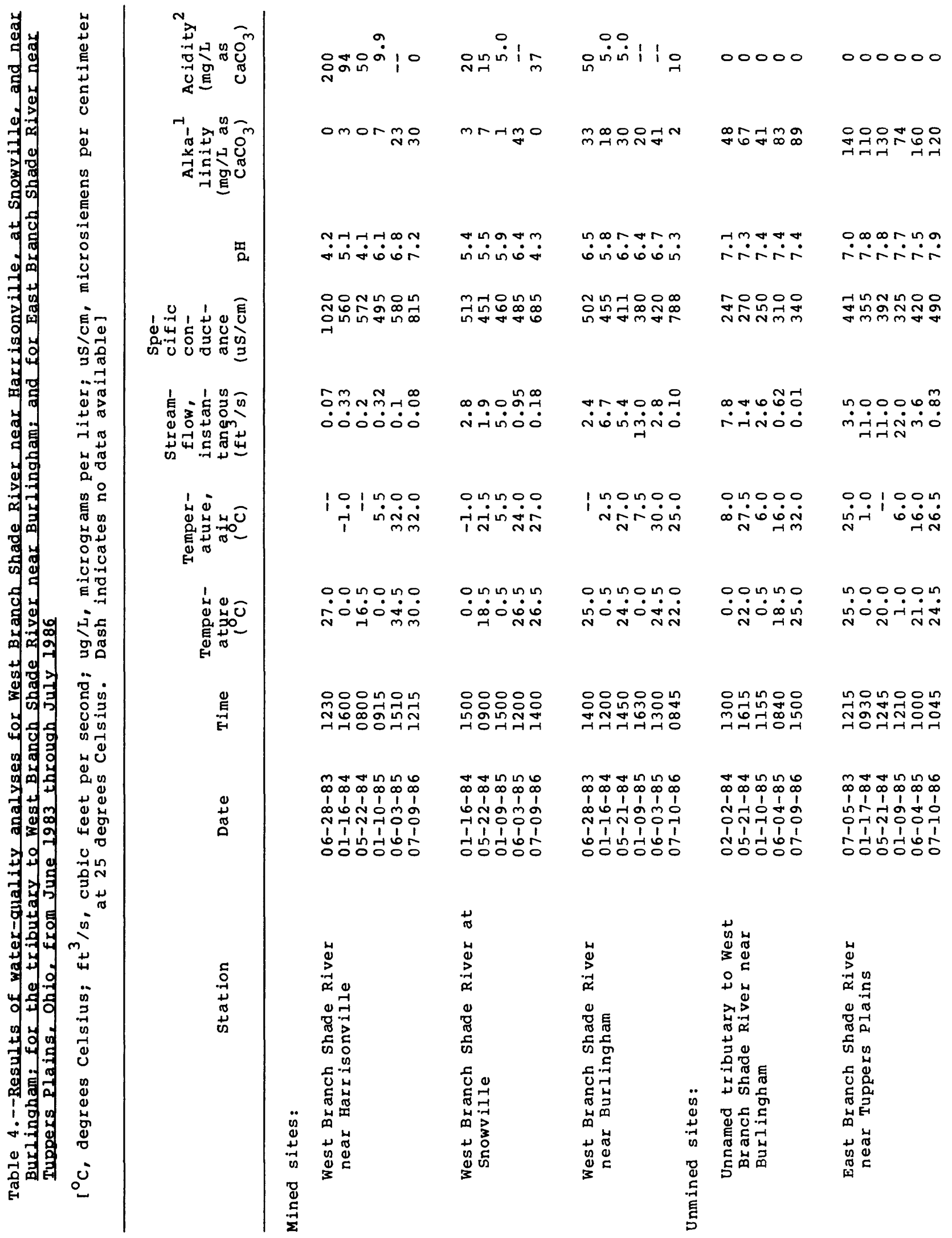




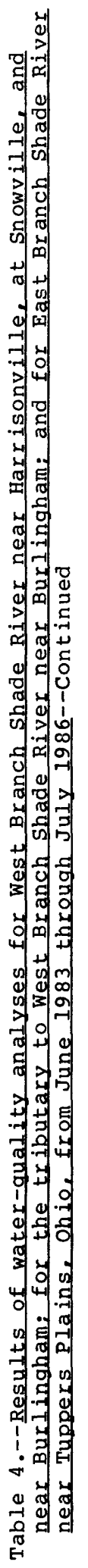

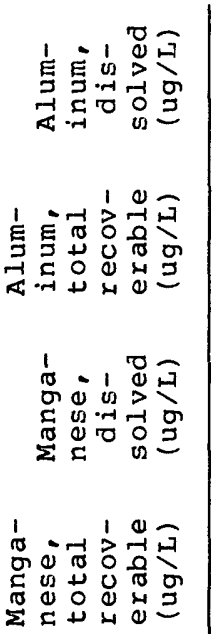

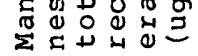

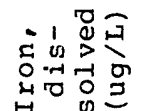

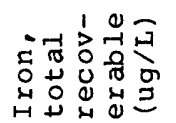

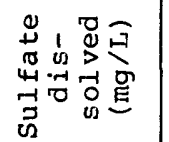

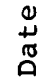

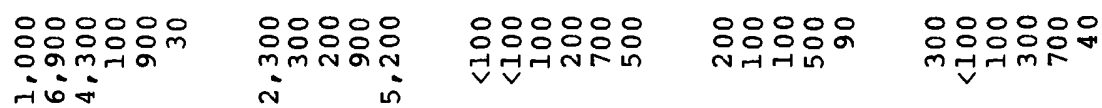

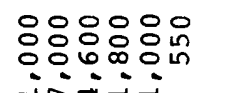

ㅇ:ㅇㅇㅛ

in

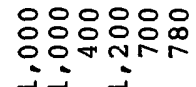

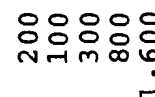

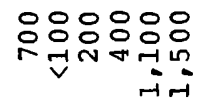

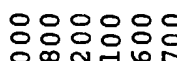

西

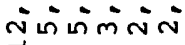

영요

응요

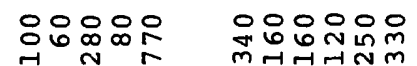

응유융ㅇำ

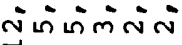

ㄱำ mंñतन

용요

눙요유

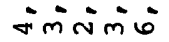

일ํํㅇㅇㅇㅇำ

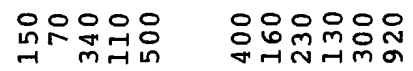
$\pi$

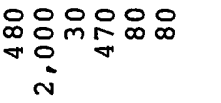

엉ㅇㅇㅇㅇㅇㅇㅇ

mंñतिं०

ก

억응유엉ㅇㅇㅇ

N

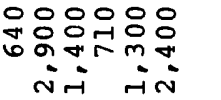

웅ㅇㅇㅇ

ลำไูก

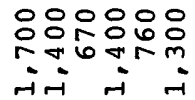

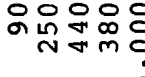

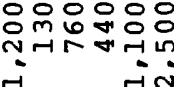

ํํํํํํำ

웅유융

윽오움우웅

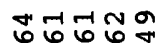

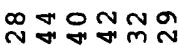

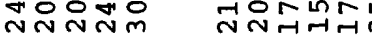

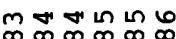

1 1 b

N 1 - 1190

ザ

$\infty$

ไ่่́

$\begin{array}{lllll}1 & 1 & 0 & 0 & 0 \\ 1 & 1 & 1 & 1\end{array}$

m『山

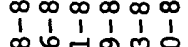

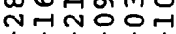

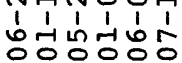

サ

$\begin{array}{lllll}\infty & \infty & \infty & \infty & \infty \\ 1 & 1 & 1 & 1 & 1 \\ 0 & -1 & 0 & 0 & 0\end{array}$

ONनIO

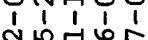

엉ㅇㅇㅇㅇ

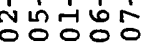

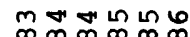

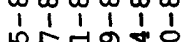

OनNOON

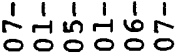

党

崩

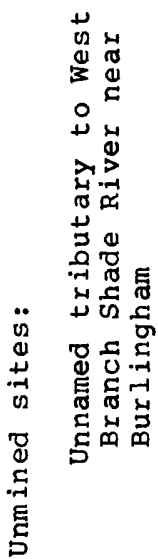

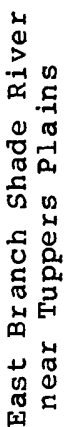

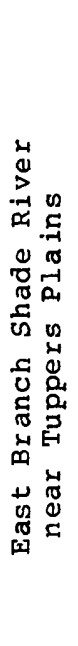

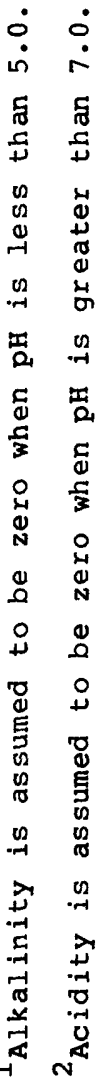


Previous studies have shown that, in southeastern ohio, concentrations of manganese and sulfate typically remain at prereclamation levels even after reclamation (Childress, 1984; Pfaff and others, 1981). In fact, sulfate and manganese concentrations are typically reliable indicators of past disturbance from surface mining.

\section{SUMMARY AND CONCLUSIONS}

Daily mean streamflow and suspended-sediment concentrations were measured from June 1983 through October 1985 at three streamflow gages located in the Shade River basin--East Branch Shade River near Tuppers Plains and West Branch Shade River near Harrisonville and Burlingham. In addition, water samples for chemical-quality analyses were collected at five locations on East and West Branches, and channel cross sections were surveyed at 10 locations from June 1983 through September 1986. East Branch Shade River basin has never been mined for coal, whereas there are more than 900 acres of abandoned-mine lands in West Branch Shade River basin.

During the study period, about 450 acres of abandoned-mine lands were reclaimed, including all of the abandoned-mine lands above the Harrisonville site and 41 percent of the abandonedmine lands above the Burlingham site. The mean annual suspendedsediment concentrations at the two sites in West Branch basin were more than twice as $h i g h(0.5 I$ and 8.6 ton per acre-foot of runoff) in the 1984 water year (before the completion of reclamation activities) as the mean annual suspended-sediment concentrations for the unmined East Branch basin 10.28 ton per acre-foot of runoff). In the 1985 water year, after the completion of reclamation activities, mean annual suspended-sediment concentration decreased at Harrisonville to 0.15 ton per acre-foot of runoff and was unchanged near Burlingham (0.49 ton per acre-foot of runoff). Mean annual suspended-sediment concentration also was unchanged for the unmined East $\mathrm{Br}$ anch basin in 1985.

Surveys of stream cross sections were made at least twice a year and were used to calculate a cross-section area. The cross section surveyed in the headwaters of West Branch Shade River basin near Harrisonville had scoured. This was confirmed by $v$ isual observation of the streambed and by changes in the stagedischarge relation over the study period. The cross section surveyed near Burlingham, however, appeared to be filling. The cross section surveyed at Snowville appeared to be in equilibrium, neither filling nor scouring consistently over the period of study. Although the source of sediment from the headwaters has been greatly reduced because of reclamation, the sediment previously deposited in the channel continues to provide a sediment supply. In addition, there is a continuing supply from the remaining abandoned mines. 
Of the tributaries to West Branch Shade River that were surveyed, only one series of cross sections, on Kingsbury Creek, indicated a change in channel configuration. This cross section was scouring over the study period. The channel configuration of two cross sections in the headwaters of Kingsbury Creek and nearest to the abandoned-mine lands appear to be in equilibrium over the study period.

Water quality for the West Branch Shade River basin was characteristic of streams draining abandoned-mine lands. In general, $\mathrm{pH}$ and alkalinity concentrations were low and acidity, dissolved-sulfate, and dissolved-manganese concentrations were high compared with East Branch Shade River and the tributary draining an unmined part of West Branch Shade River basin.

Improvements in water quality at West Branch Shade River near Harrisonville were observed following a significant amount of reclamation. All abandoned mines in the headwaters of West Branch Shade River basin were reclaimed by the end of the study period. Alkalinity concentrations and $\mathrm{pH}$ values in the headwaters were higher at the end of the study than at the beginning of the study at nearly identical streamflow. Dissolved-manganese concentrations were lower at the end of the study compared with the beginning of the study, although concentrations were still an order of magnitude higher than at the unmined sites.

\section{SELECTED REFERENCES}

American Public Health Association, 1975, Standard methods for the analysis of water and wastewater, 14 th edition: p. 275-277.

Brant, R. A., and Delong, R. M., 1960, Coal resources of Ohio: Ohio Division of Geological Survey Bulletin 58, $245 \mathrm{p}$.

Childress, C. J. O., 1984, Classification of stream basins in southeastern Ohio according to extent of surface coal mining: U.S. Geological Survey Water-Resources Investigations Report $84-4212,83 \mathrm{p}$.

Childress, C. J. O., and Jones, R. L., 1985a, Sediment and waterquality data for the West Branch and East Branch Shade River basins, Ohio, 1983 water year: U.S. Geological Survey OpenFile Report 85-187, 16 p.

- - 1985b, Sedimentation and water quality in the West Branch Shade River Basin, Ohio, 1984 water year: U.S. Geological Survey Water-Resources Investigations Report 85-552, 26 p.

Colby, B. R., 1956, Relationship of sediment discharge to streamflow: U.S. Geological Survey Open-File Report, 170 p. 
Fenneman, N. M., 1938, Physiography of eastern United States: New York, McGraw-Hill, 691 p.

Foster, G. R., and Meyer, L. D., 1977, Soil erosion and sedimentation by water--An overview, in National Symposium on Soil Erosion and Sedimentation by Water: Chicago, IL, p. 1-13.

Guy, H. P., 1969, Laboratory theory and methods for sediment analysis: U.S. Geological Survey Techniques of WaterResources Investigations, book 5, chap. Cl, 58 p.

Happ, S. C., Rittenhouse, G., and Dobson, G. C., 1940, Some principles of accelerated stream and valley sedimentation: U.S. Department of Agriculture Technical Bulletin 695, 133 p.

Hirsch, R. M., Slack, J. R., Smith, R. A., 1982, Techniques of trend analysis for monthly water-quality data: Water Resources Research, v. 18, no. 1, p. 107-21

Leopold, L. B., Wolman, M. G., Miller, J. P., 1964a, Fluvial Processes in geomorphology: W. H. Freeman and Company, San Francisco, 522 p.

Ohio Board of Unreclaimed Strip Mine Lands, 1974, Land reborn: Ohio Department of Natural Resources, $91 \mathrm{p}$.

Pfaff, C. L., Helsel, D. R., Johnson, D. P., and Angelo, C. G., 1981, Assessment of water quality in streams draining coalproducing areas in Ohio: U.S. Geological survey water Resources Investigations/Open-File Report 81-409, 98 p.

-Porterfield, G., 1972, Computation of fluvial-sediment discharge: U.S. Geological Survey Techniques of Water-Resources Investigations, book 3, chap. C3, 66 p.

Skougstad, M. W., and others, 1979, Methods for determination of inorganic substances in water and fluvial sediments: U.S. Geological Survey Techniques of Water-Resources Investigations, book 5, chap. Al, 626 p.

Trimble, S. W., 1975, Denudation studies--Can we assume stream study state: Science, v. 188, p. 1207-1208.

U.S. Department of Commerce, 1982, Climatological Data, Annual Summary, Ohio.

1983, Climatological Data, Annual Summary, Ohio.

U.S. Department of Agriculture, 1985, Assessment and Treatment of Areas in Ohio Impacted by Abandoned Mines: 73 p.

U.S. Geological Survey, 1977, Sediment, in National handbook of recommended methods for water-data acquisition. 

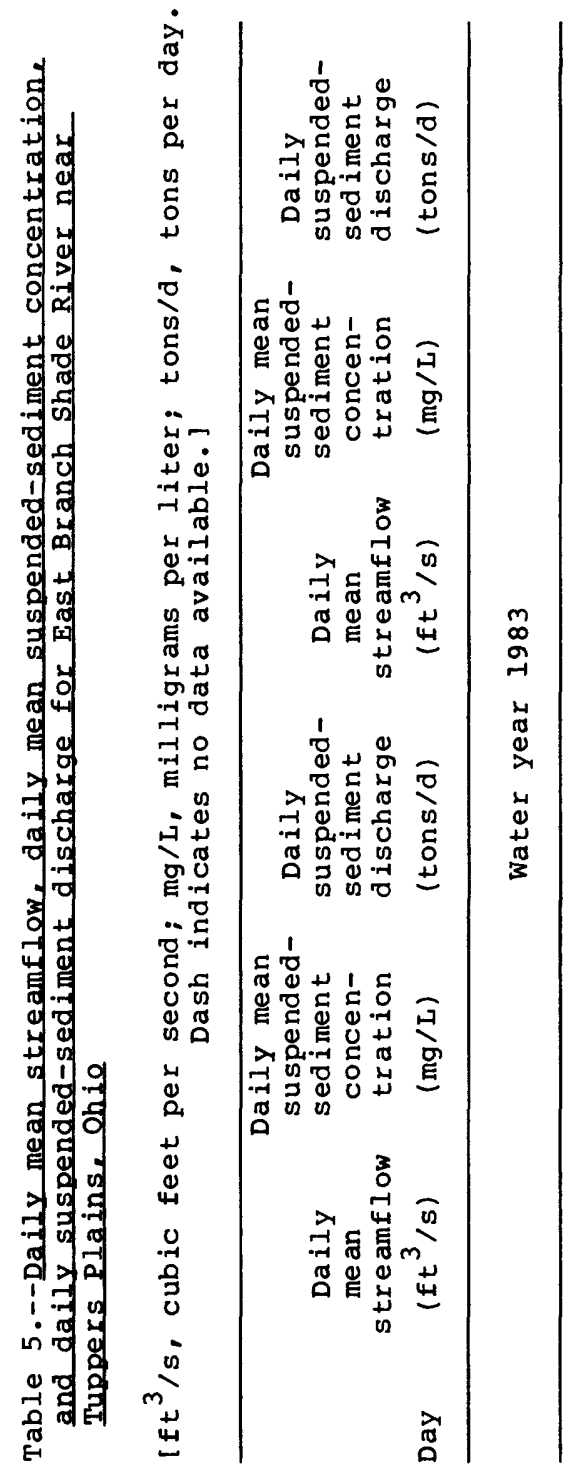

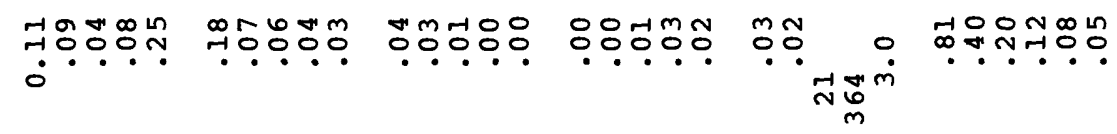
के

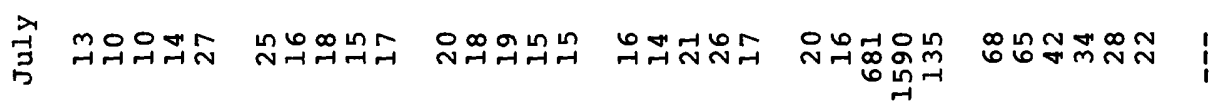

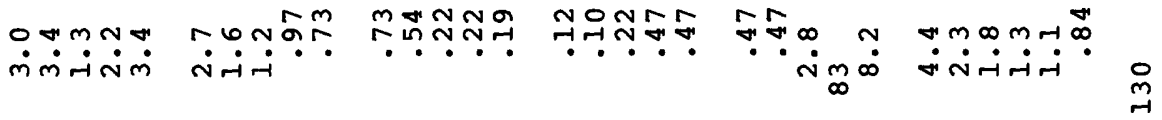

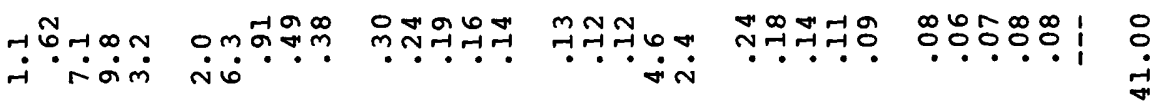

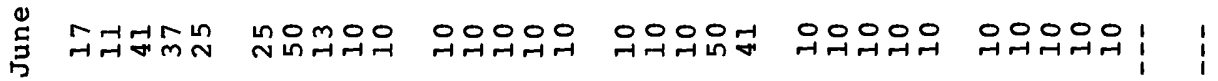

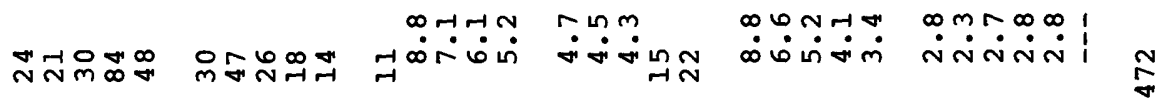

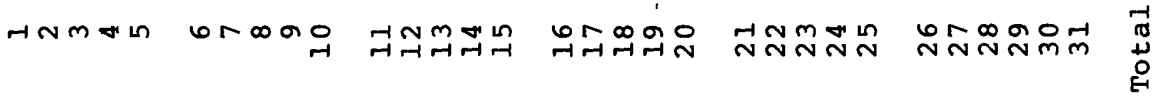




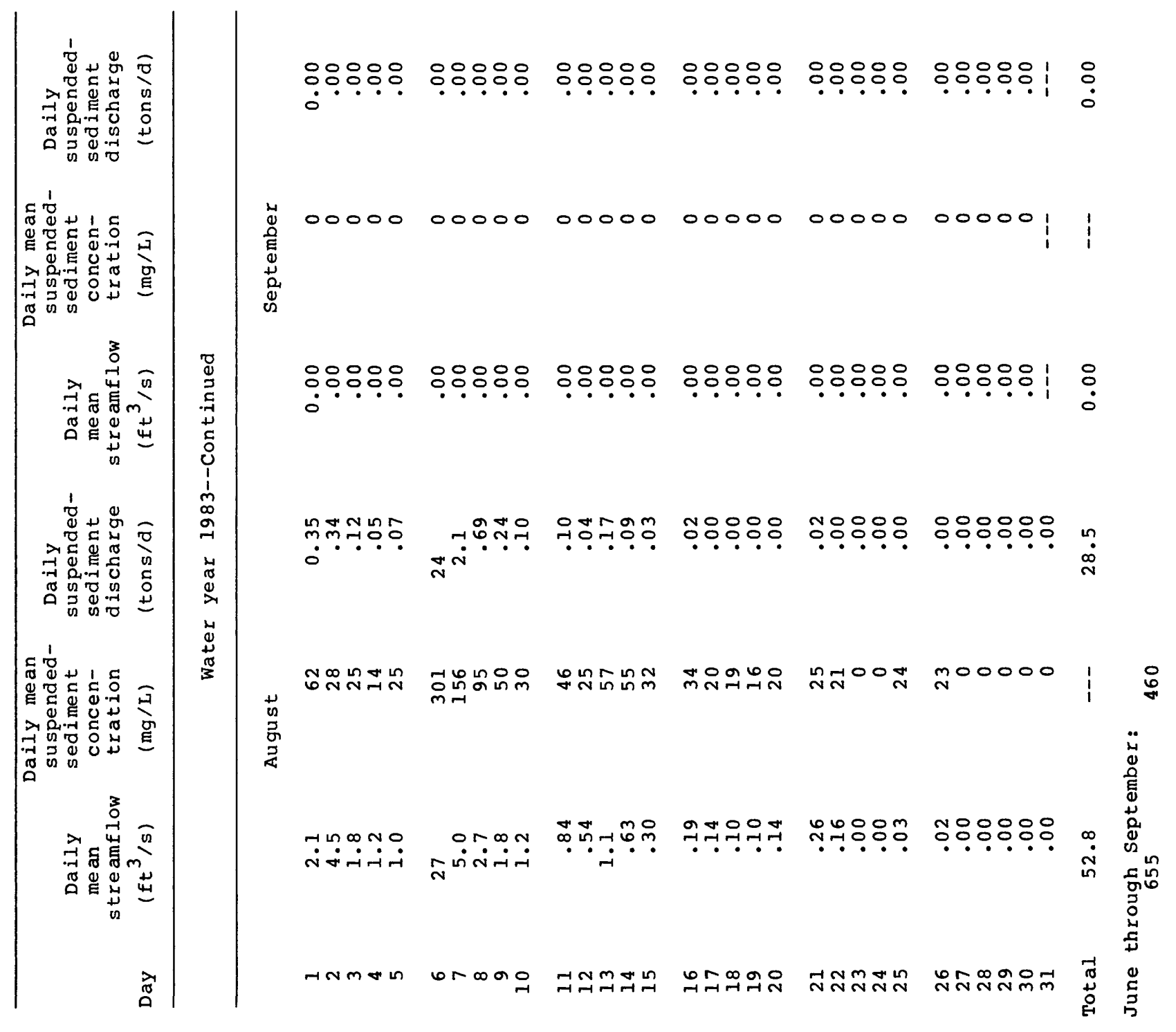




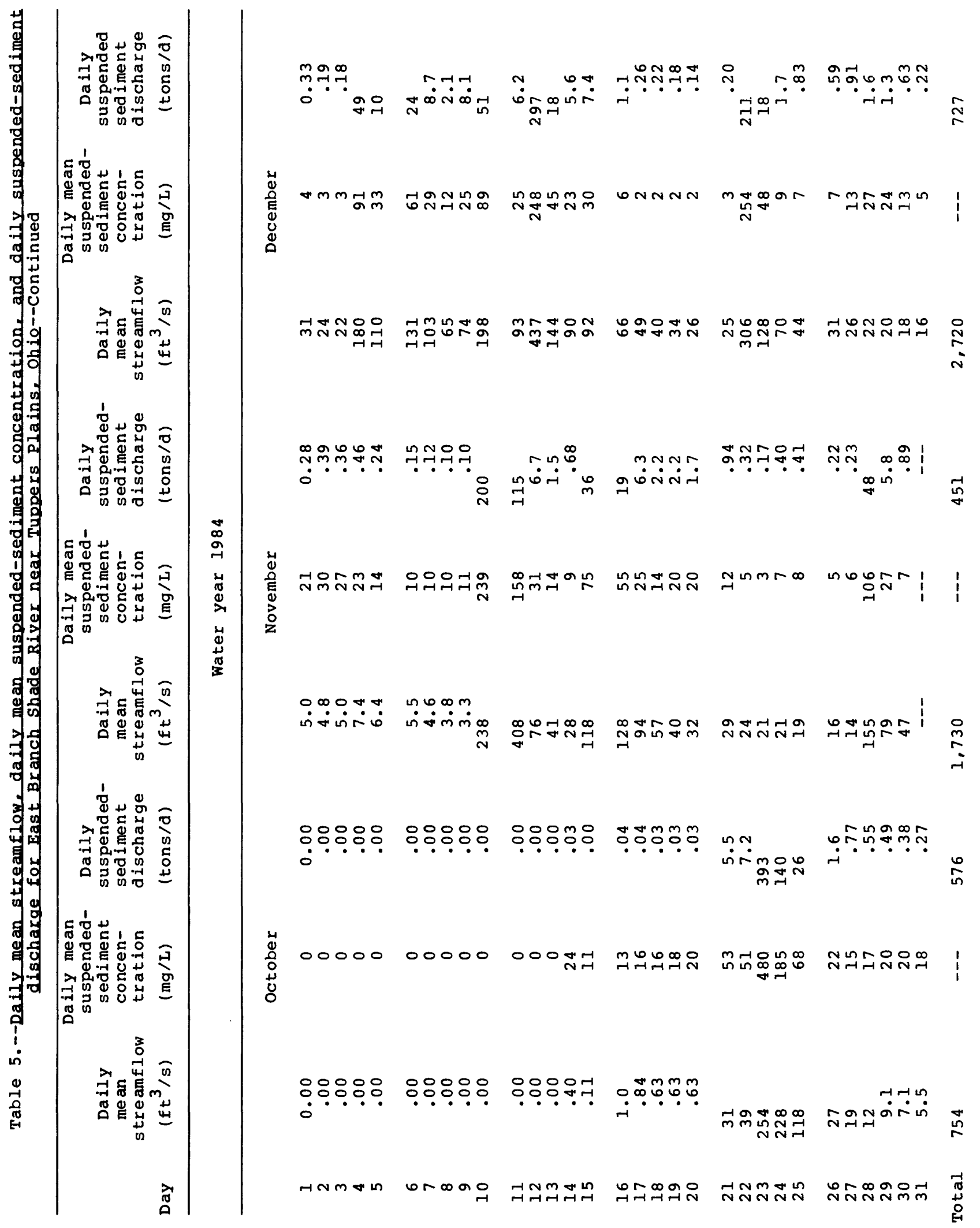




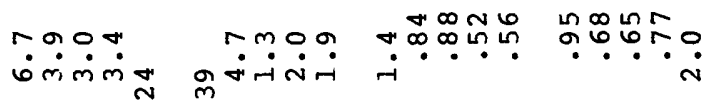

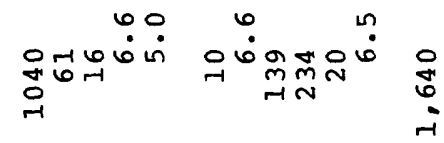

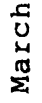

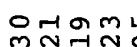

$\underset{\sim}{\pi} \stackrel{m}{\sim} \underset{r}{n}$

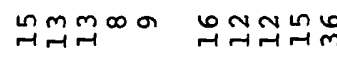

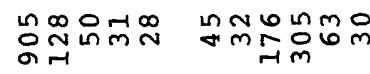

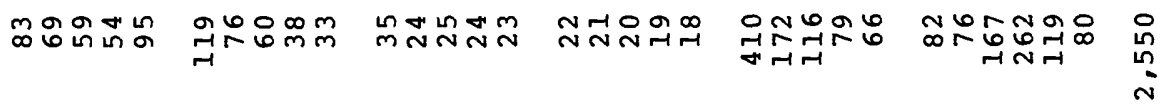

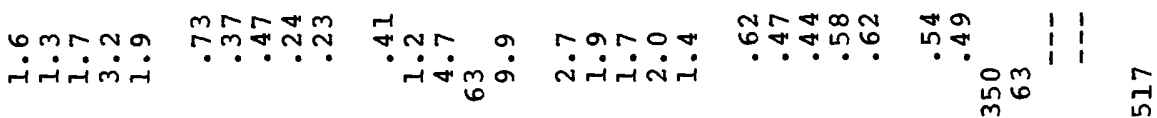

วิ

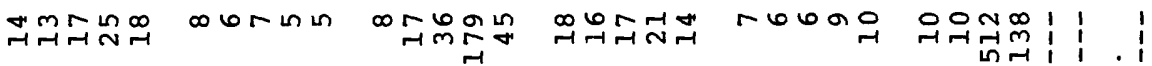

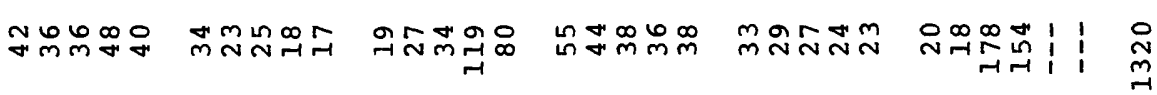

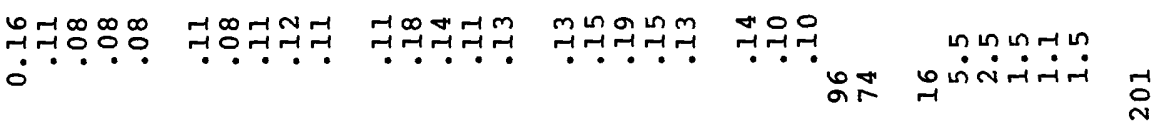

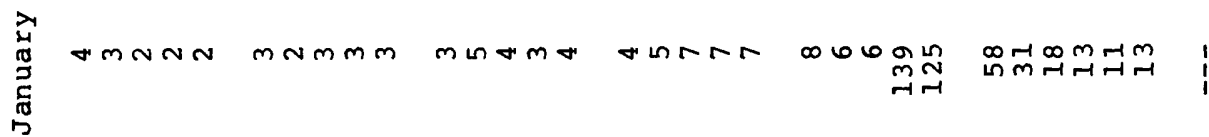

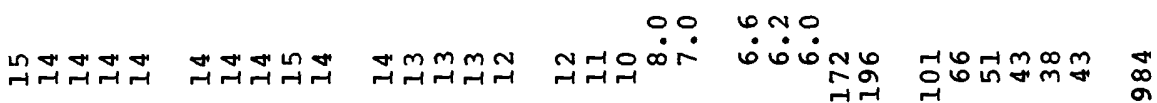

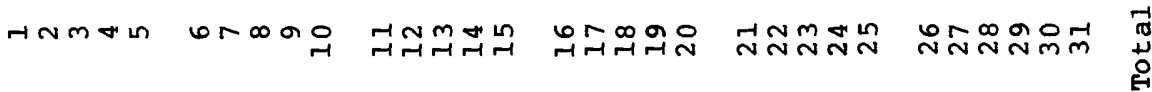




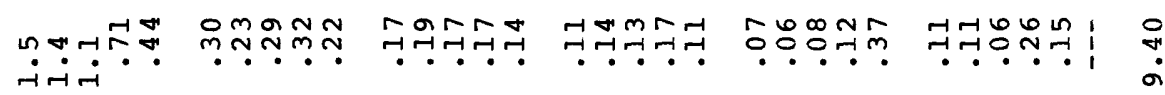

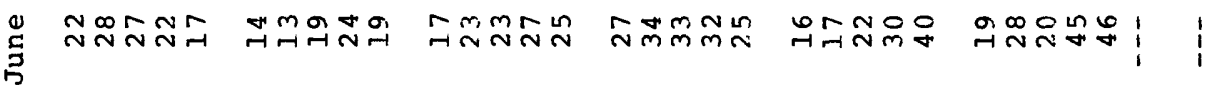

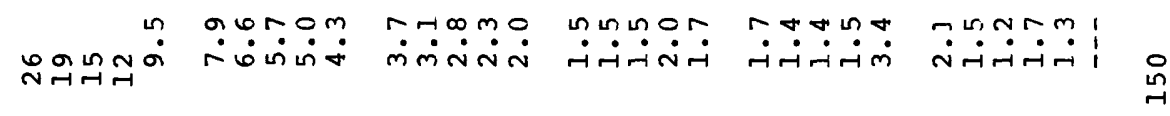

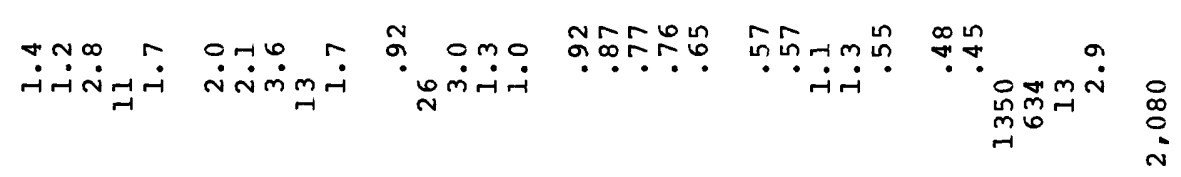

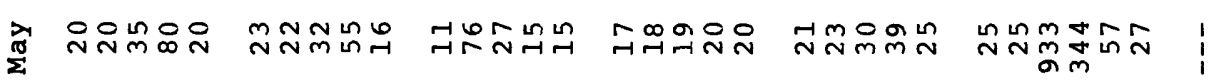

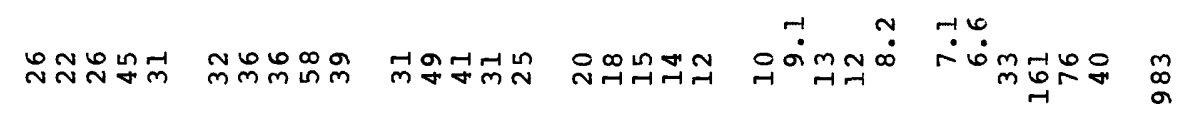

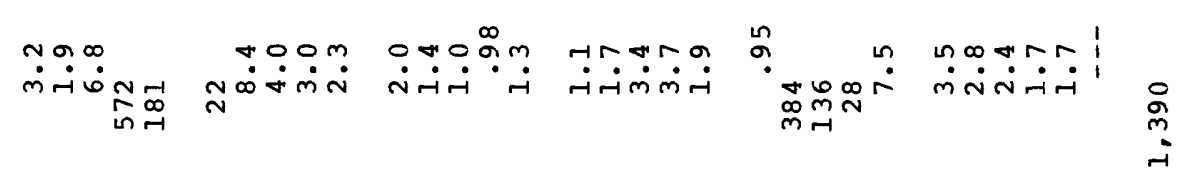

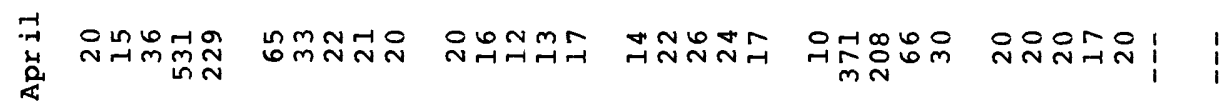

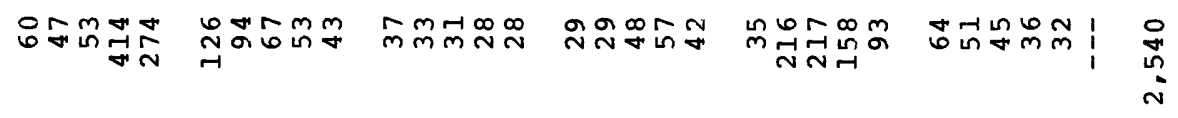

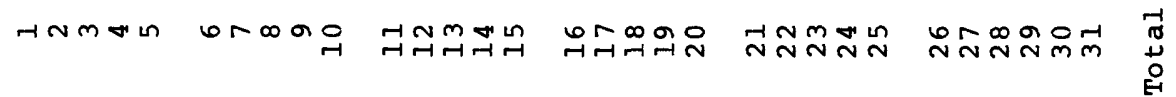




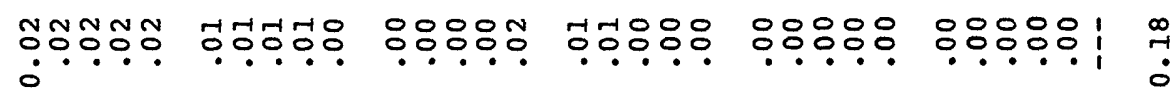

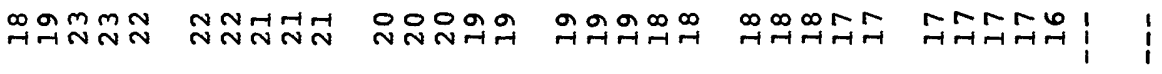

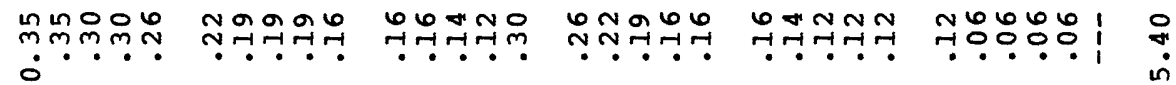

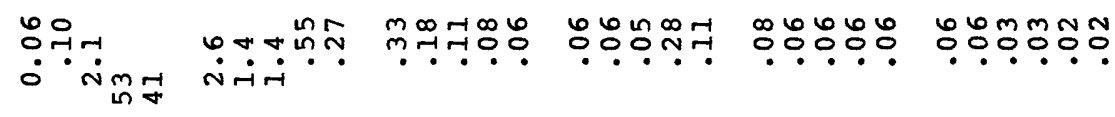

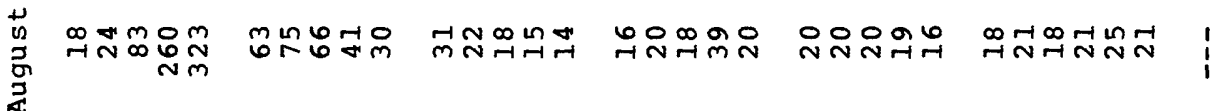

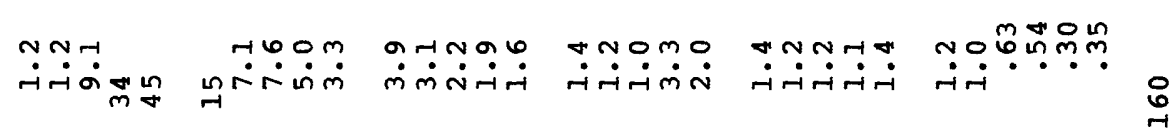
ํㅠㅁํㅇํㅇ $\stackrel{0}{\circ}$

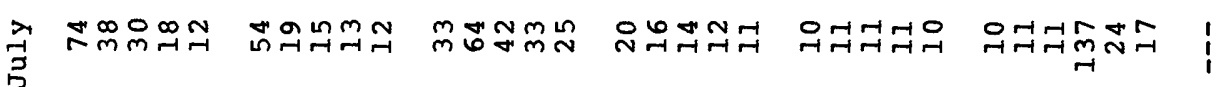

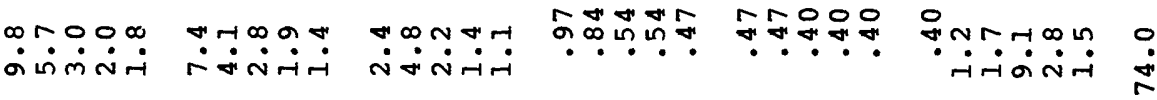

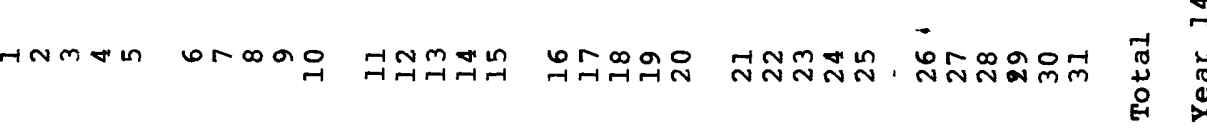




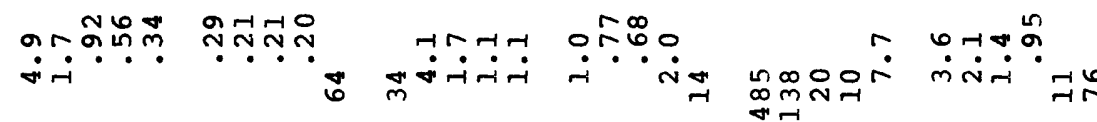

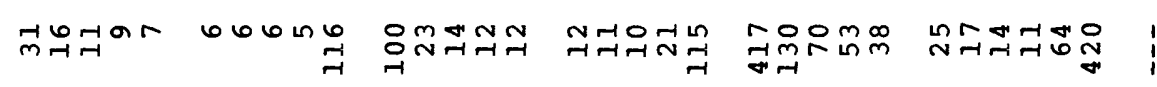

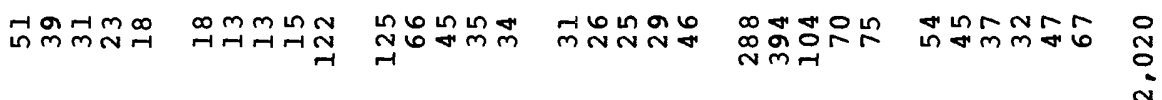

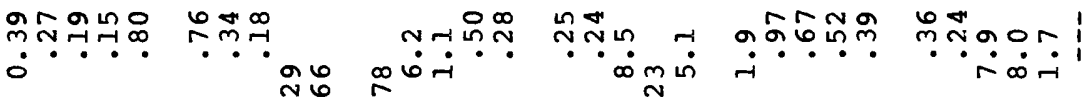

$\underset{N}{N}$

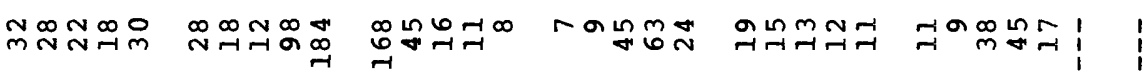

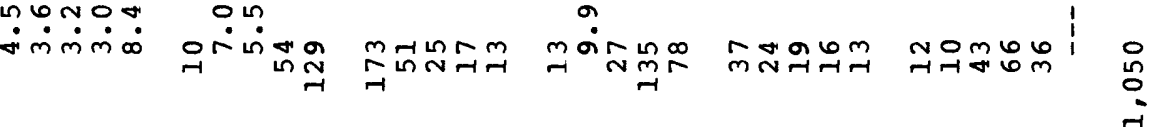

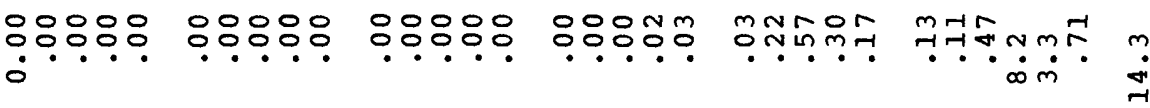

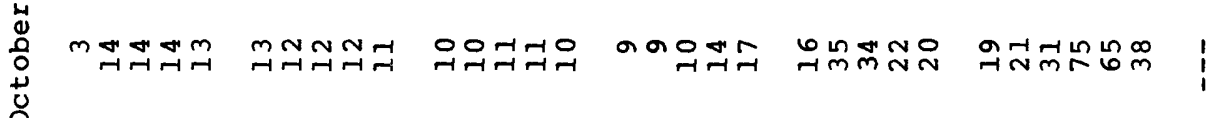

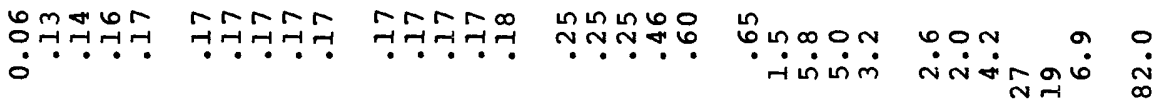

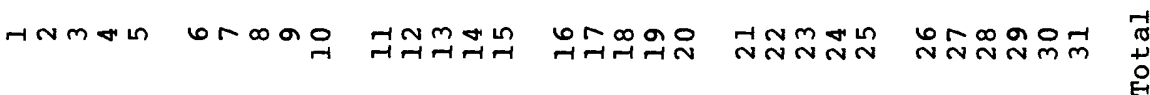




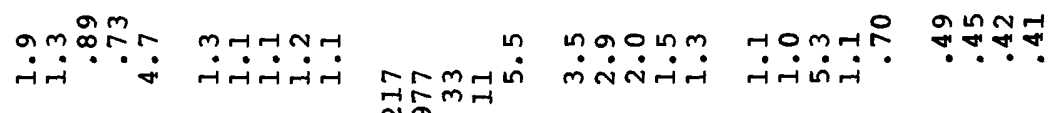

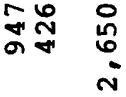

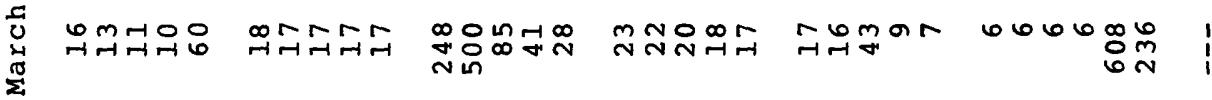

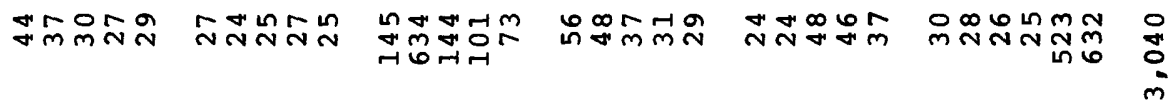

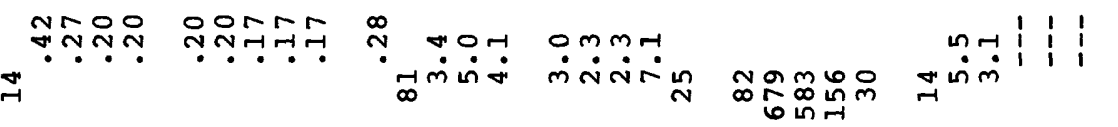

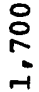

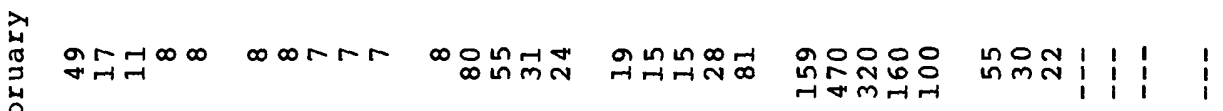
造

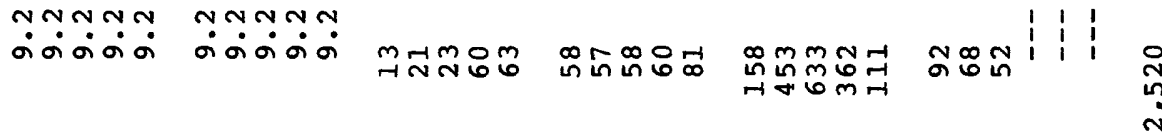

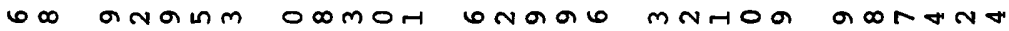
Fonmrin

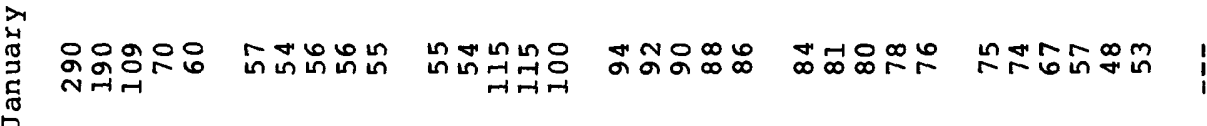

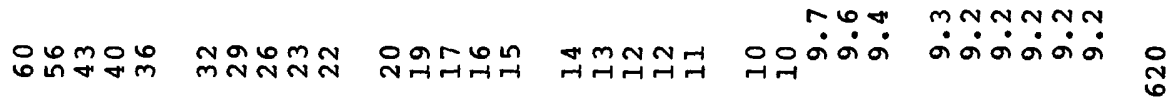

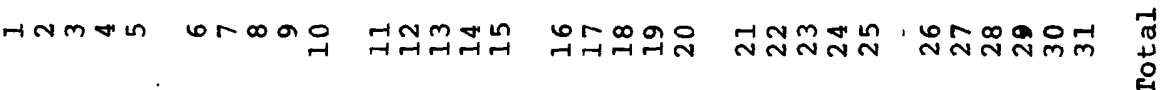




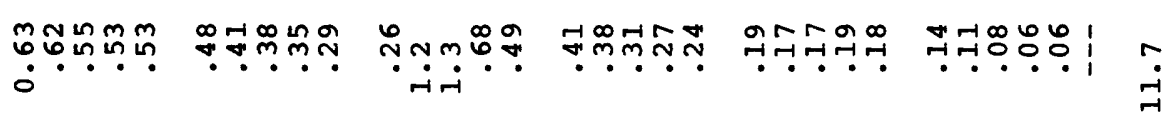

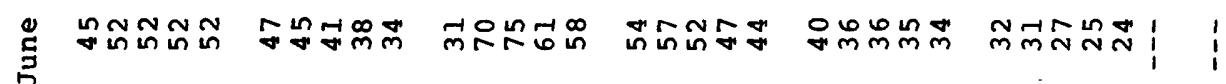

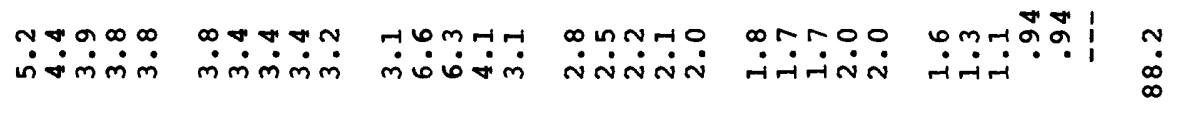

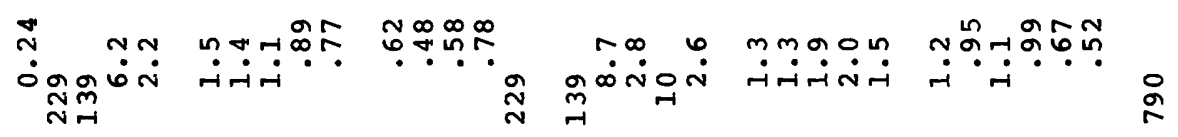

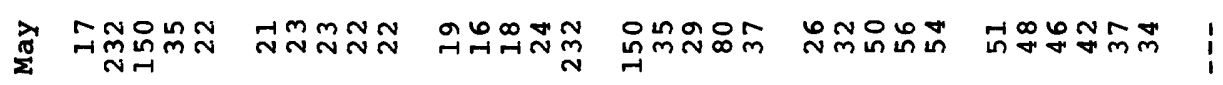

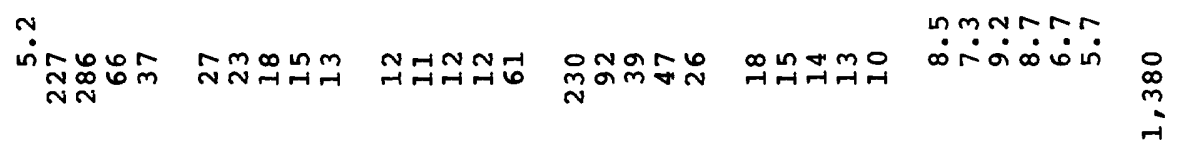

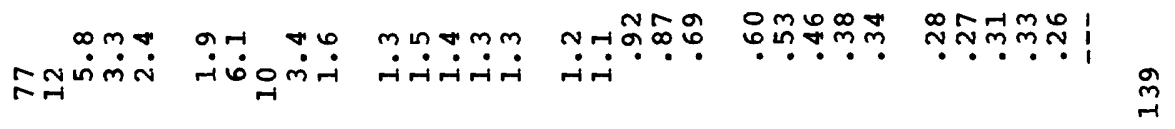

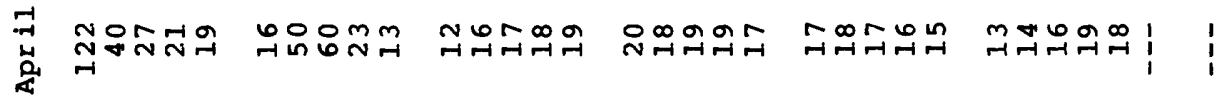

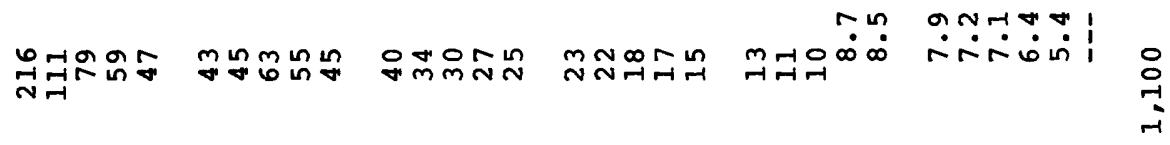

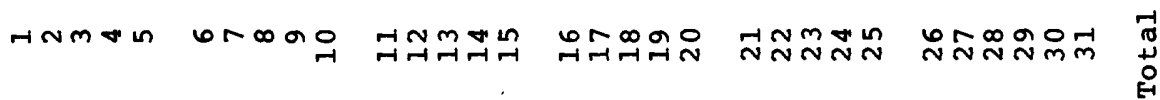




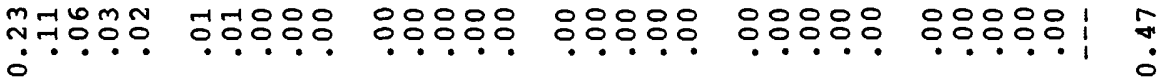

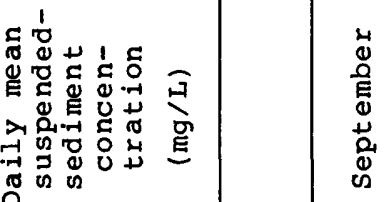

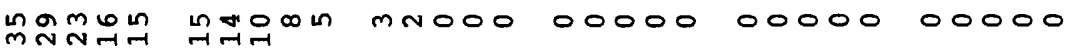

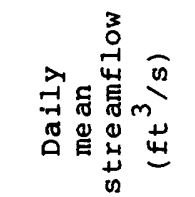

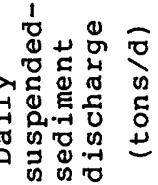
$5 \frac{1}{8}$

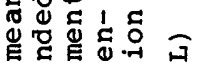

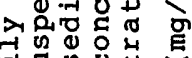

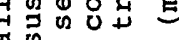
a

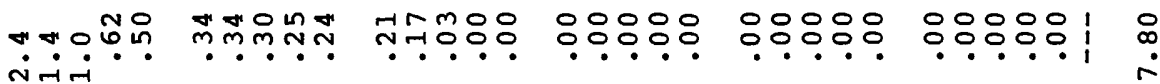

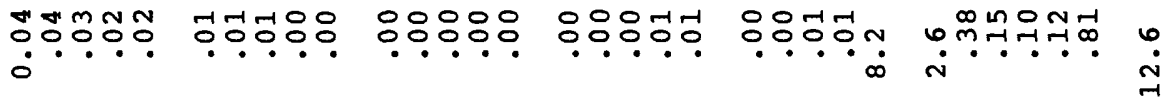

药 至

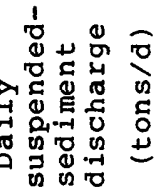

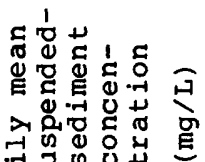
$\pi$ का

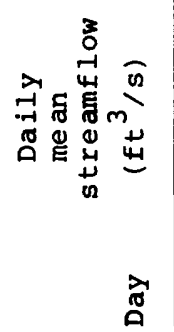

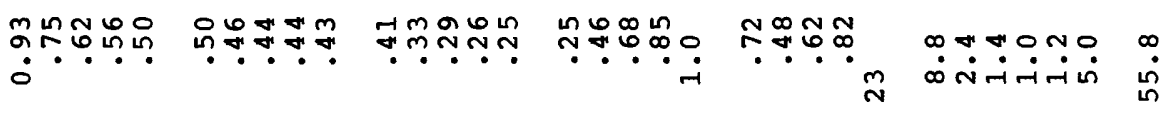

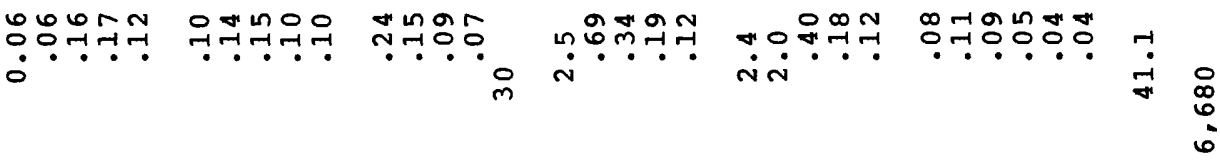

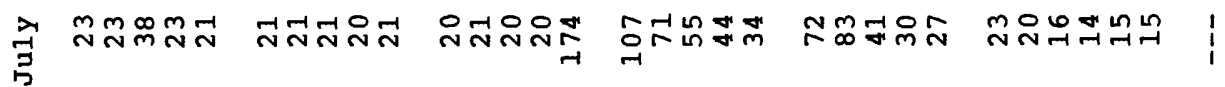

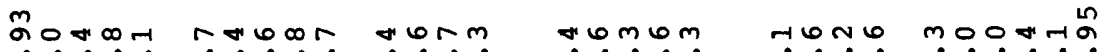

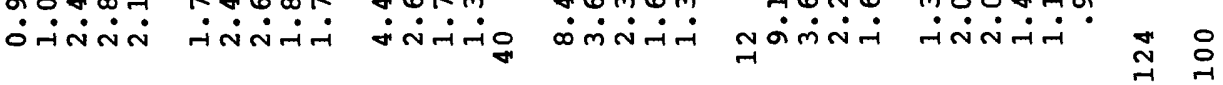

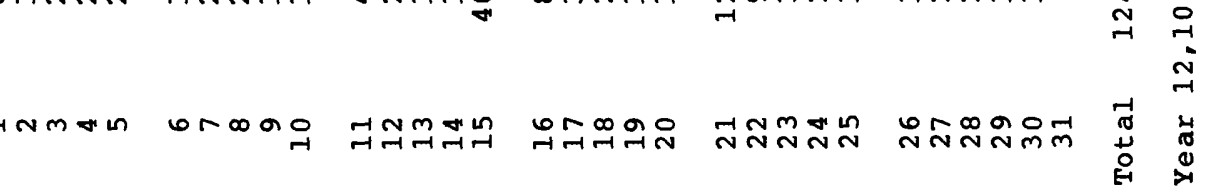




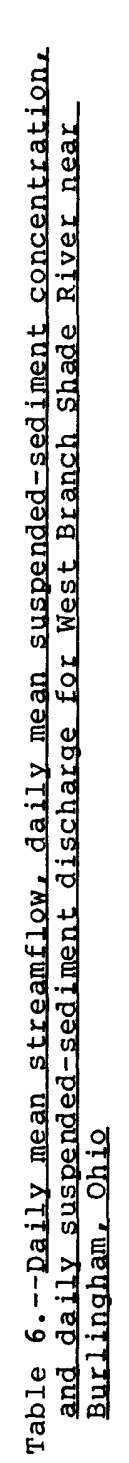

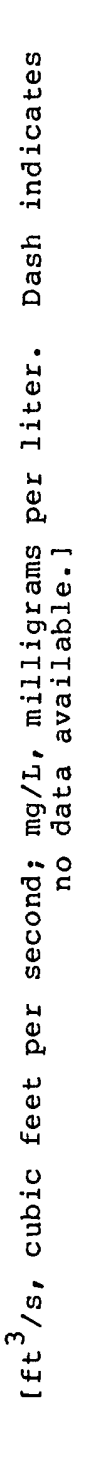

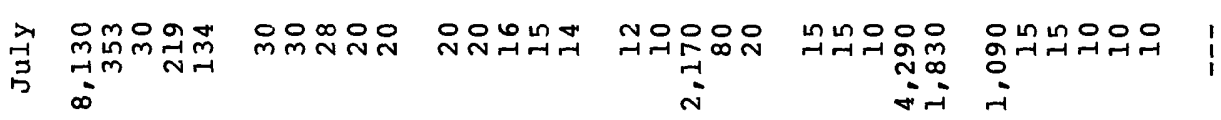

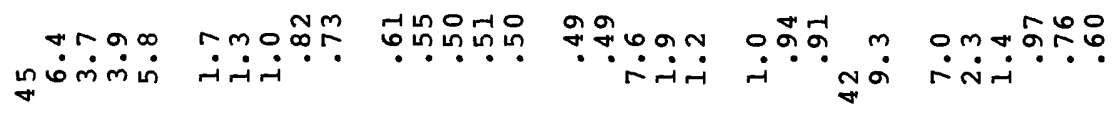
in

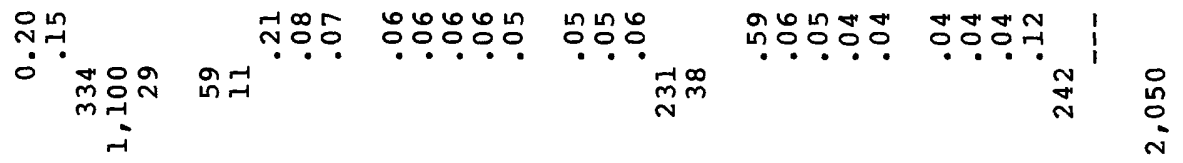

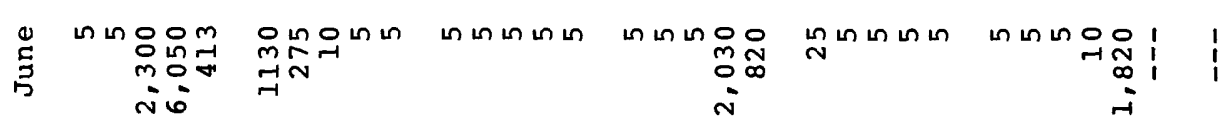

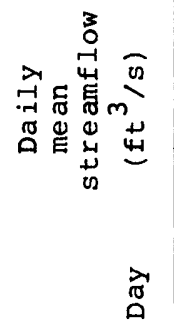

\section{bon binta mat} n=ำ $\sin \pi \sin ^{2}$ $\dot{\infty} \dot{\sim} \dot{m} \dot{m}$

$00 \mathrm{~mm}$ (1)

HNm $\rightarrow$

oriac

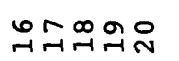

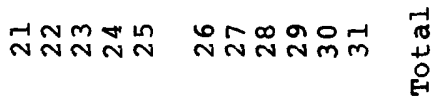




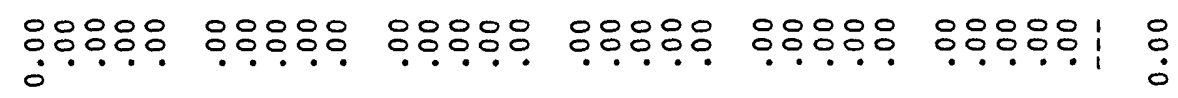

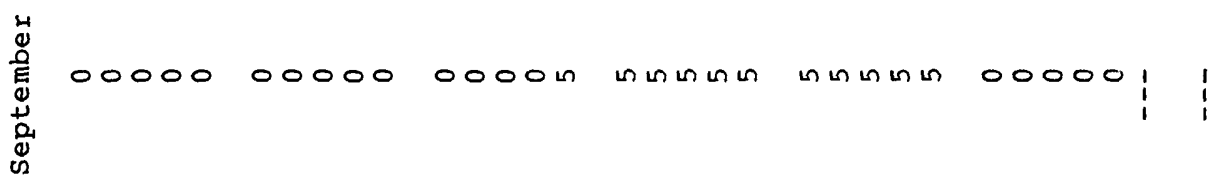

2

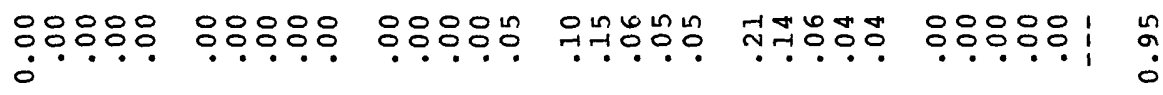

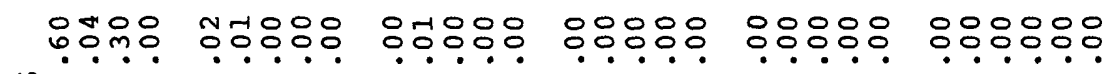

岗

$\stackrel{i}{i} \underset{\substack{i \\ \rightarrow}}{\infty}$

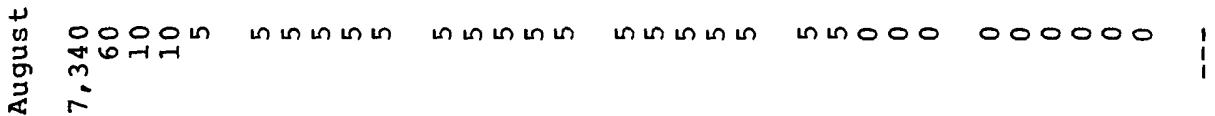

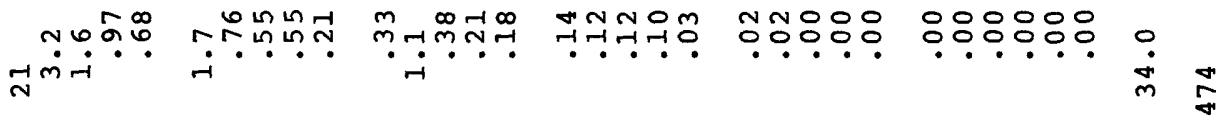

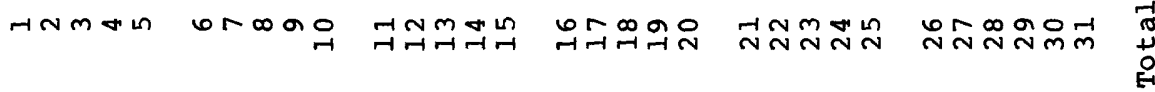

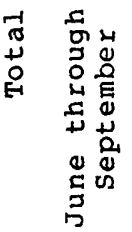




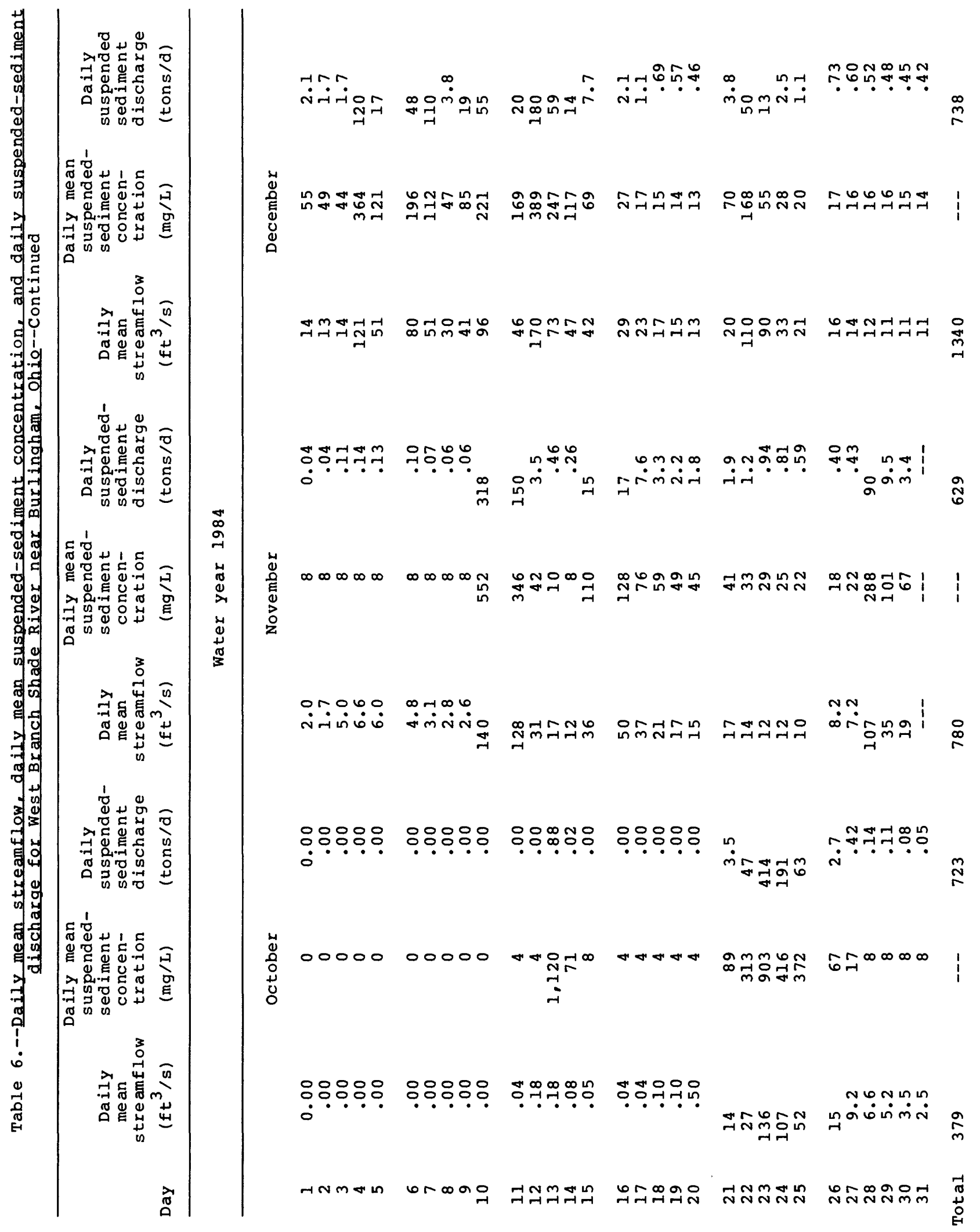


mmino

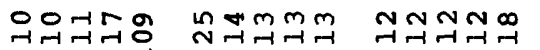

$\sum^{\pi}$

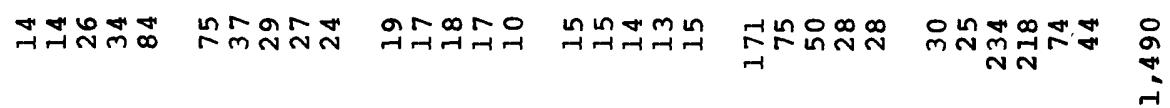

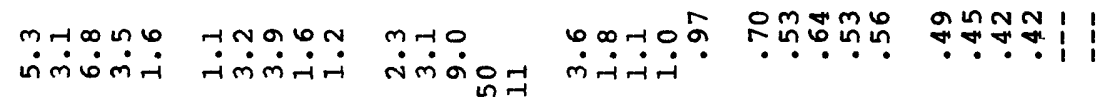

$\underset{\sim}{\stackrel{-}{r}}$

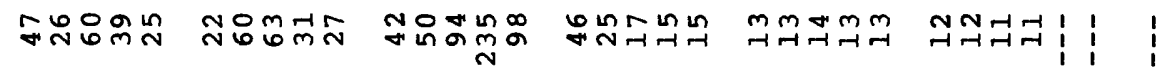

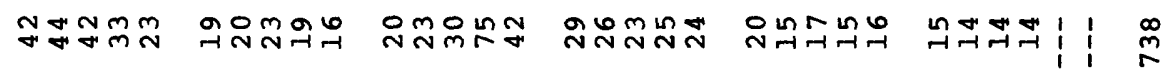

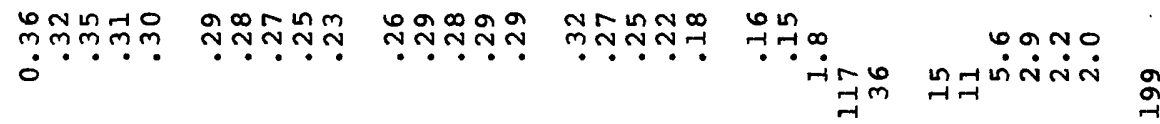

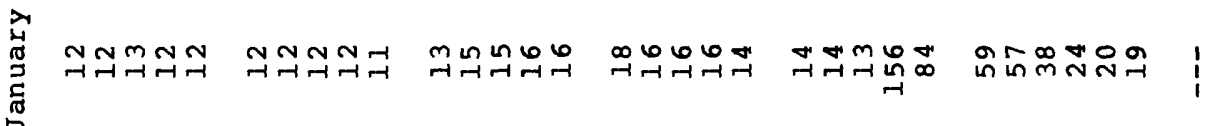

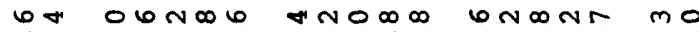

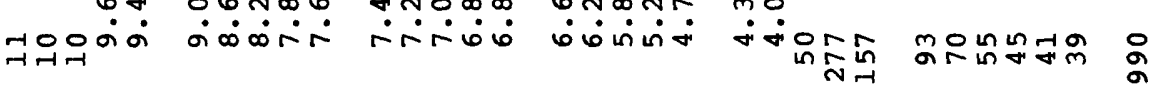

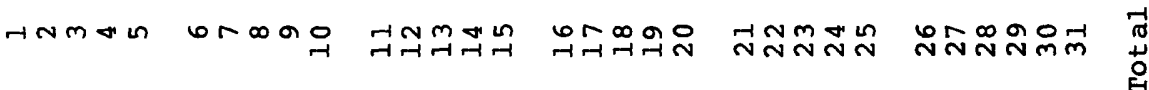




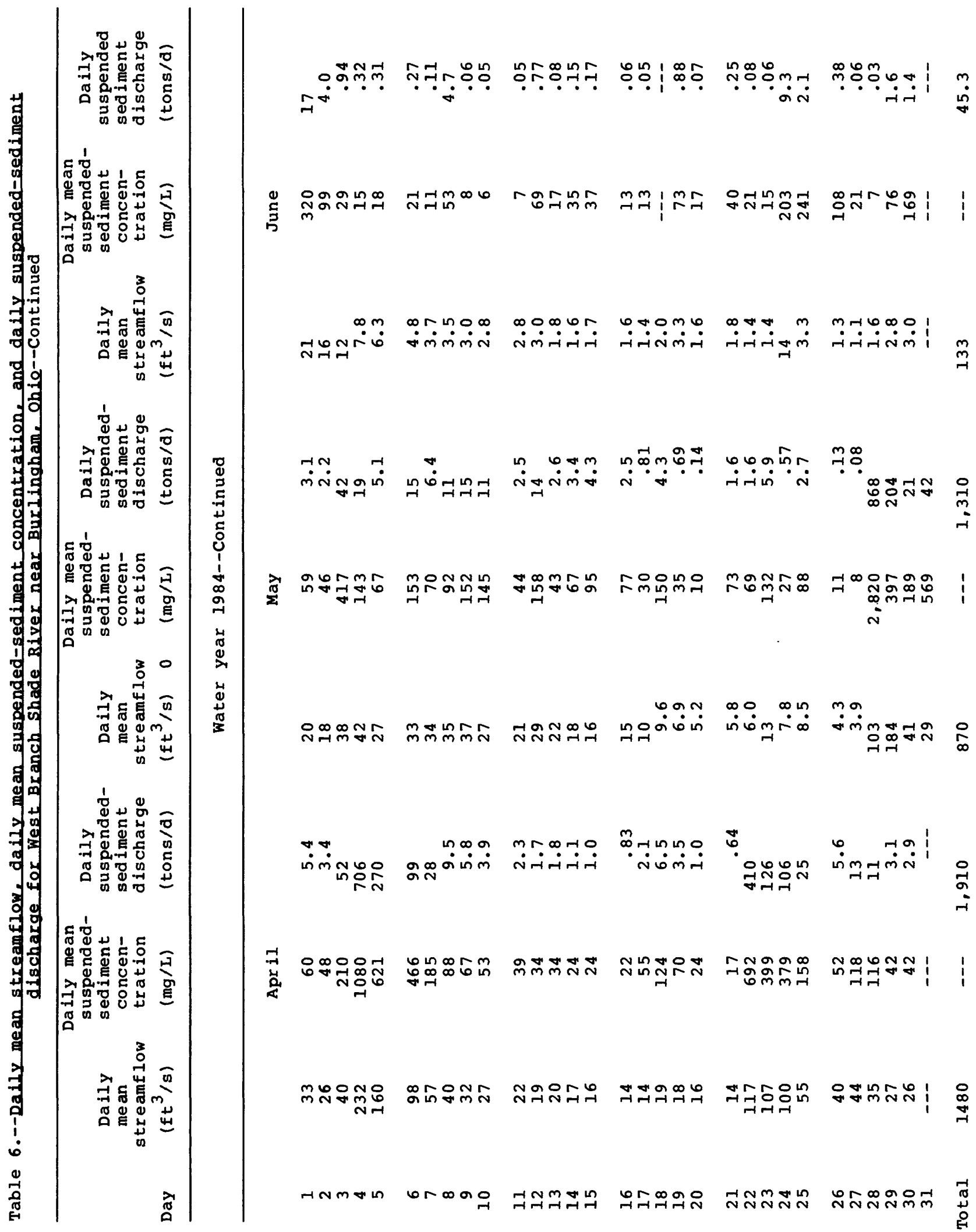


:요

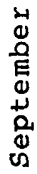

000000000000000000000000000000

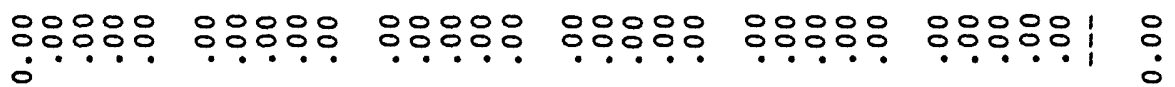

ํ.0ㅇ.

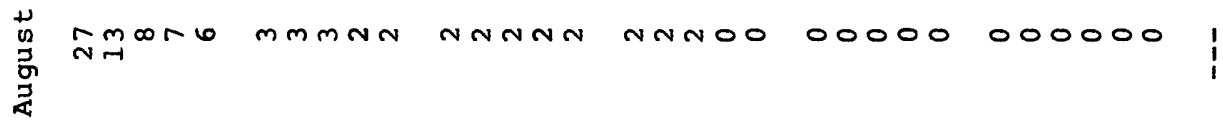

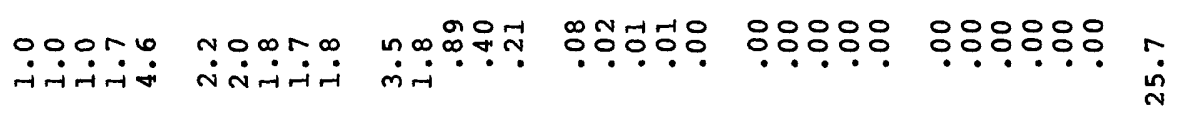

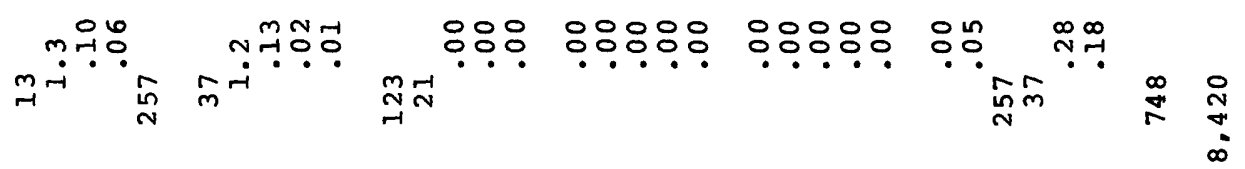

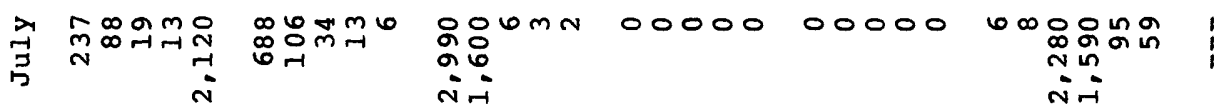

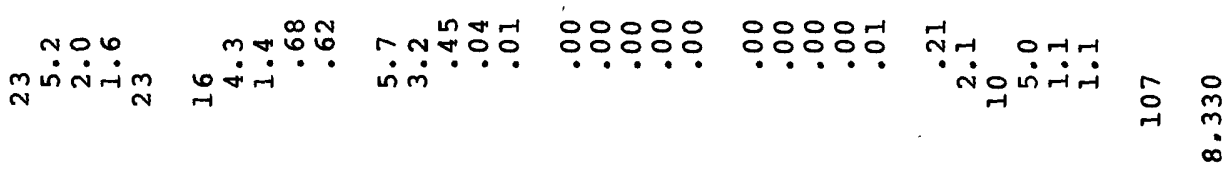

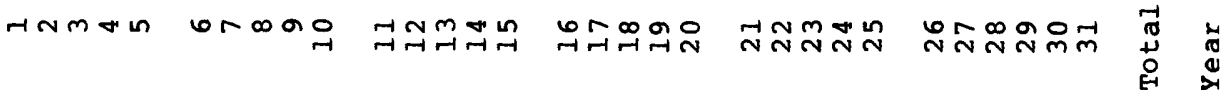




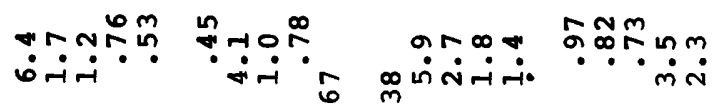

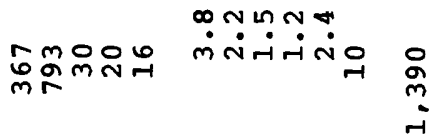

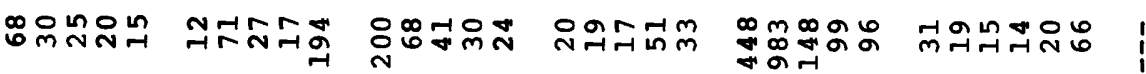

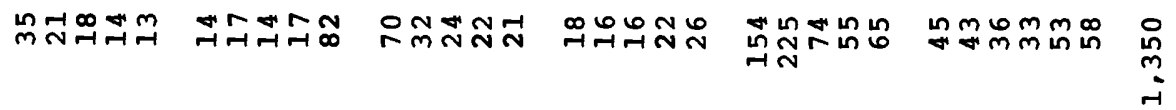

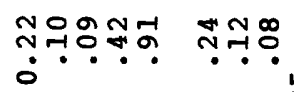

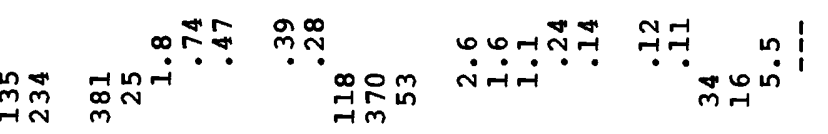

$\stackrel{\substack{\infty \\ i}}{-i}$

ดิホีที丶

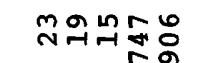

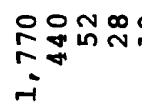

궁요

$\infty+\infty \infty$

๑

준

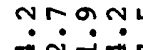

$\infty \forall a$ $-$ i<smiles>C1=CCCC1</smiles>

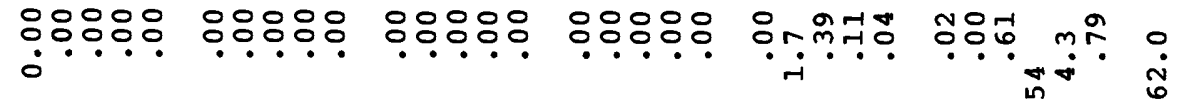

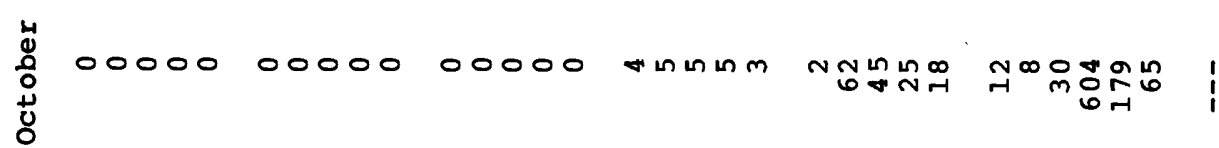

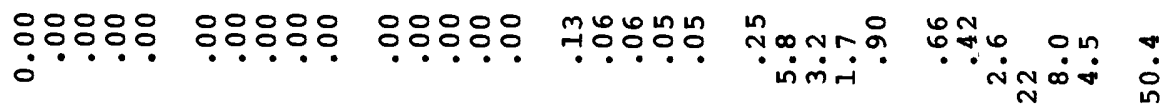

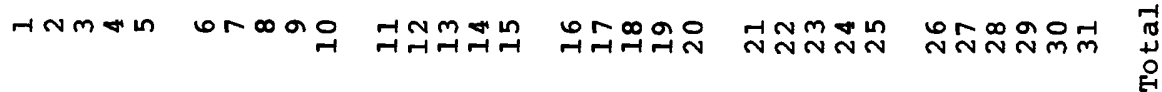




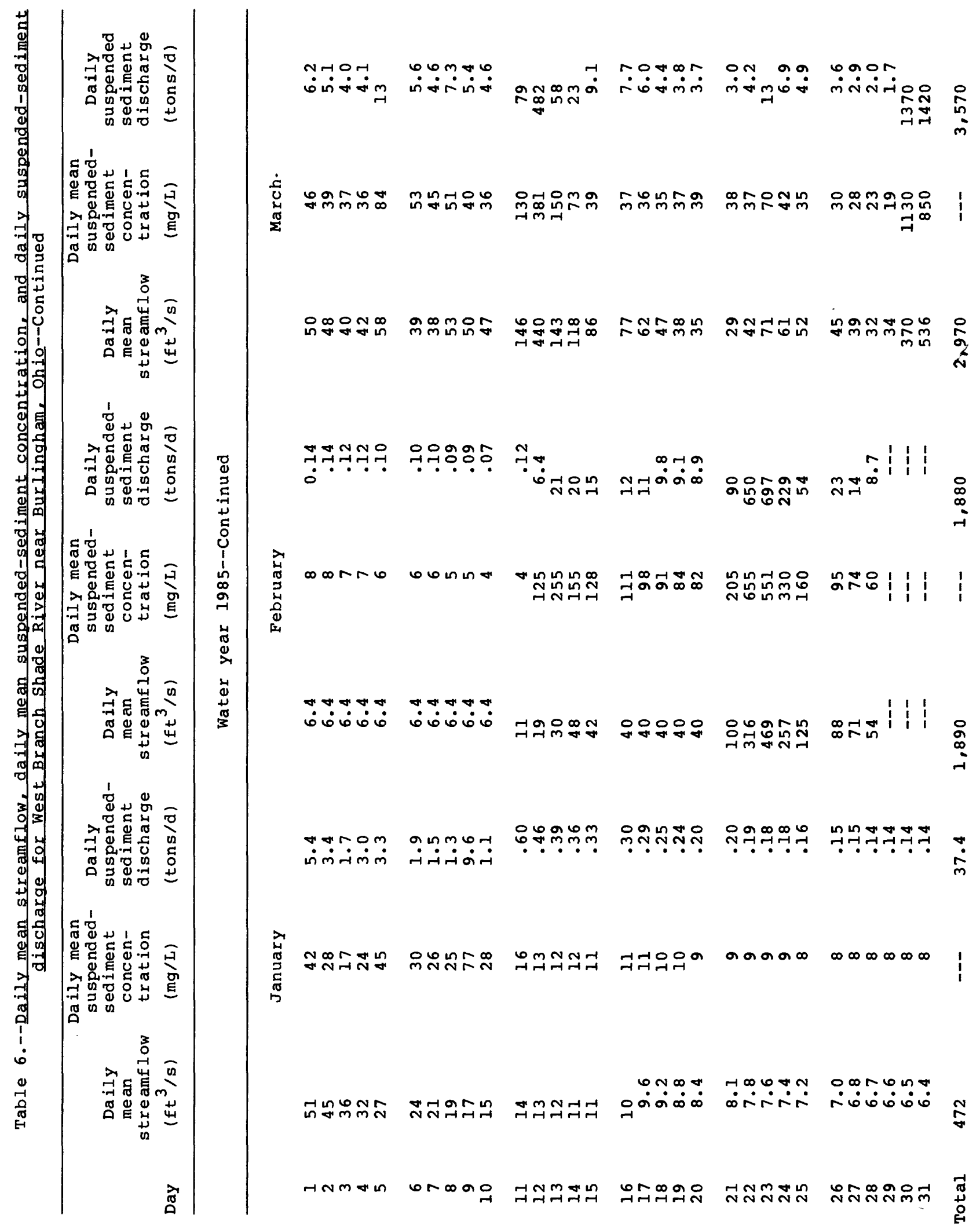




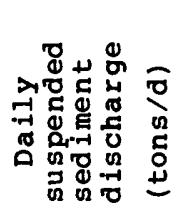

ᄃำ

415 可

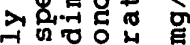
न a

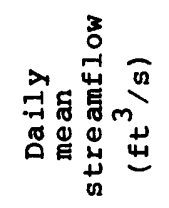

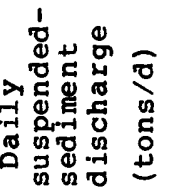

c '

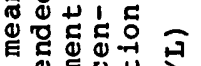

入然苋 के

न जू 0

空至

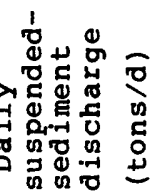

c

崖。

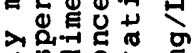

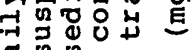

ก็ ט

热点 in

以ำㅇำ

-..

กตธัติำ

mํํํํำ

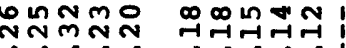

i.

・.・・

บ.ก

$\stackrel{\text { ? }}{\sim}$

$\stackrel{\text { ฐ }}{\mathfrak{5}}$

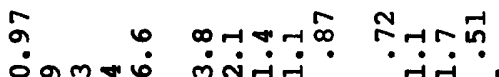

$\dot{0} \underset{\sim}{\infty} \underset{\sim}{m} \underset{N}{\infty} \dot{0}$

- $\dot{r}-$

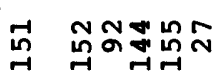

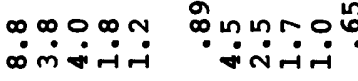

แnMOH HOणन

m. $\because+\infty$

กmm

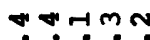

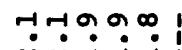

-1:

变

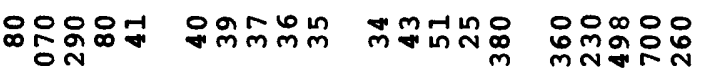

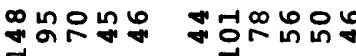

$\because 8$ 우요

in

$\operatorname{mon} 2$

?

$\ddot{\infty} \infty$

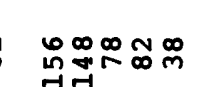

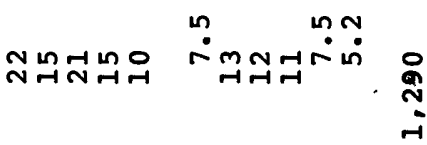

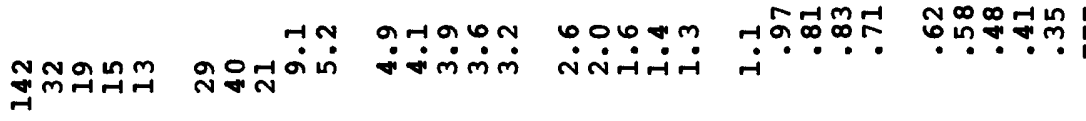

若

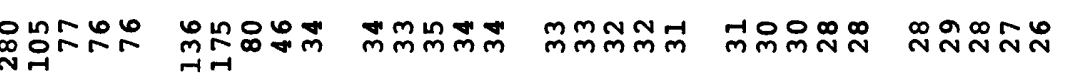

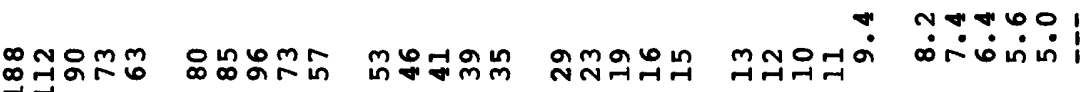

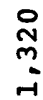

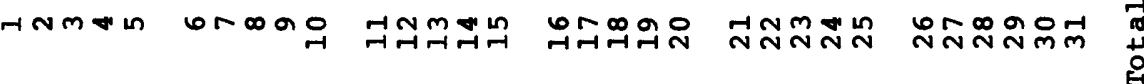




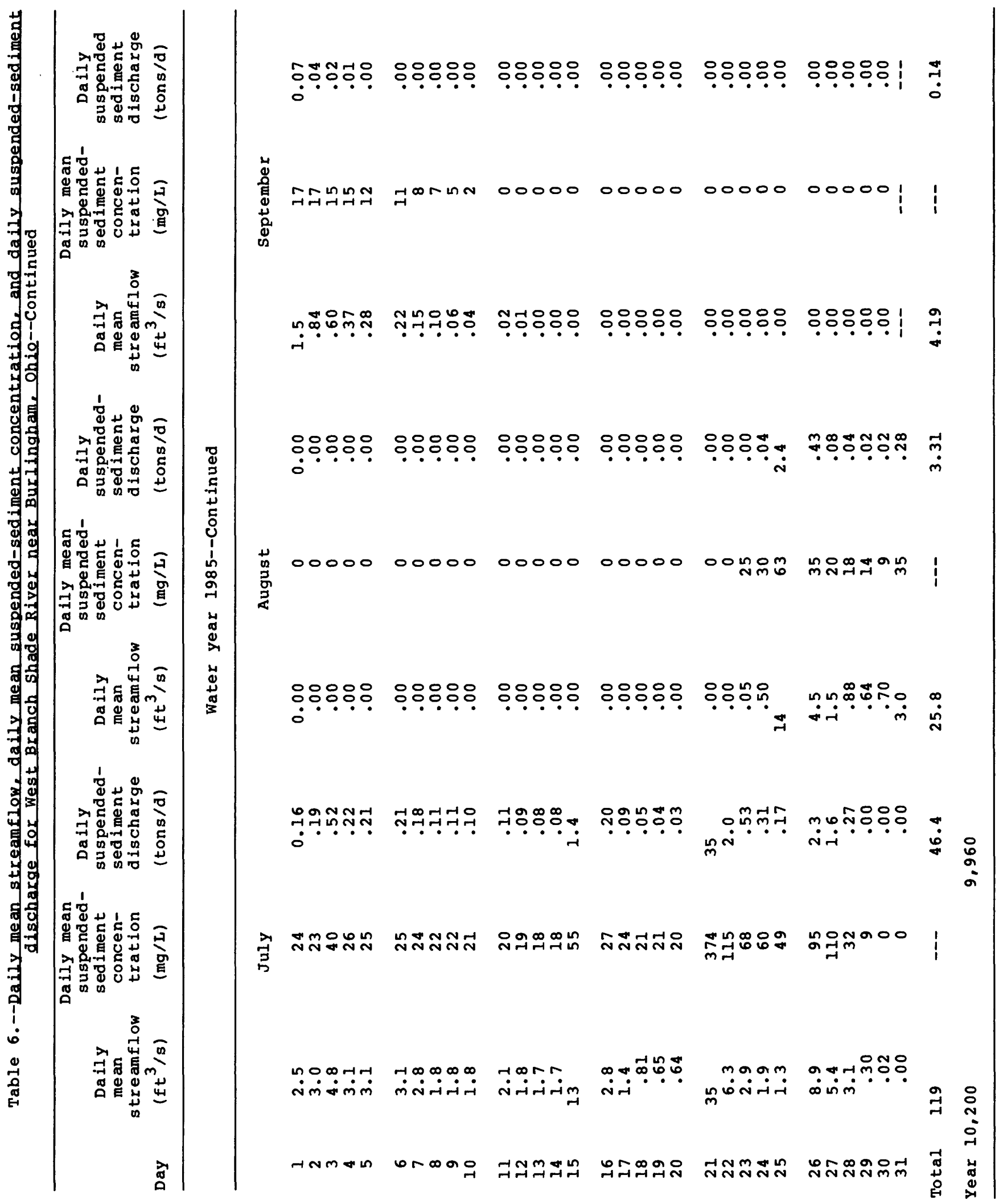




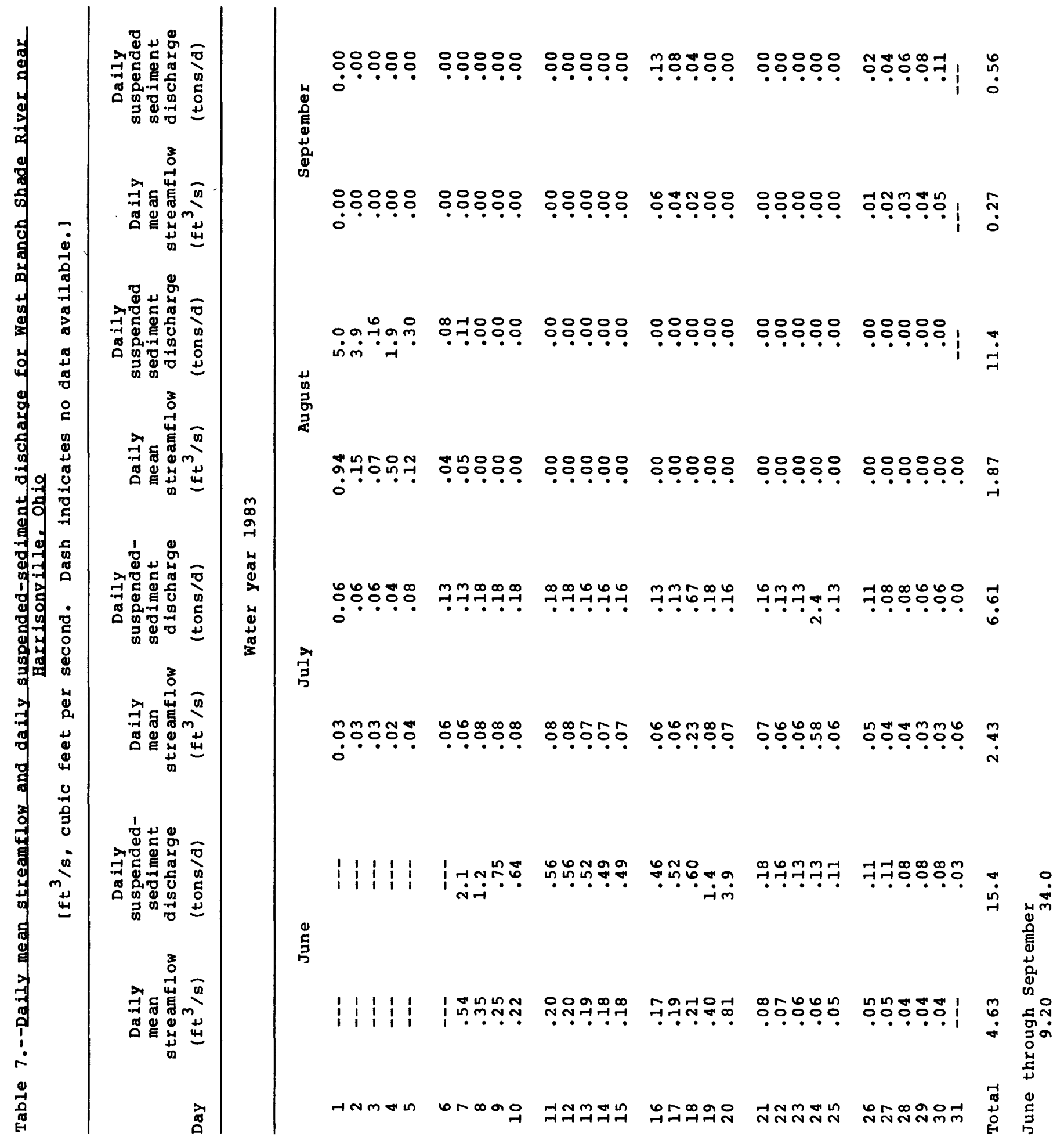


พ⿻上m荧

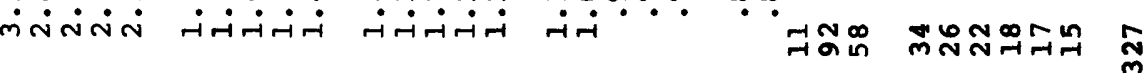

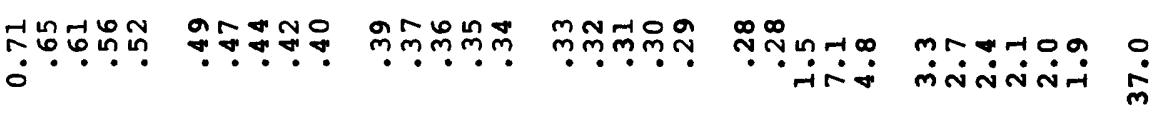

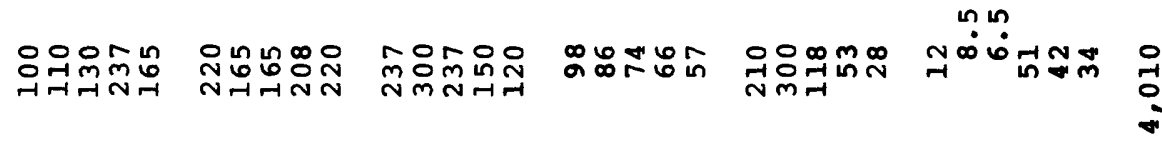

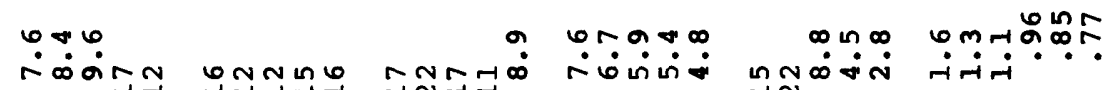

$\stackrel{\text { N }}{\text { N }}$

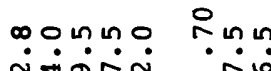

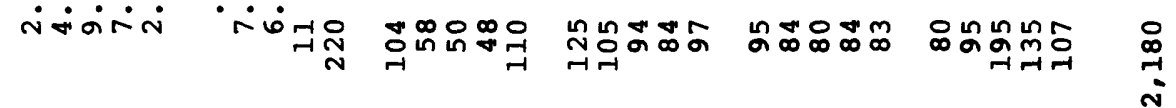

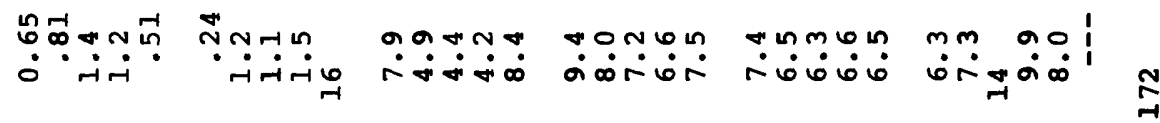

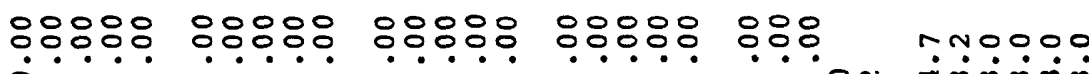
岁
.
억
$\dot{\sim} \dot{m} \dot{m} \dot{m} \dot{m}$
$\underset{\sim}{\sim}$

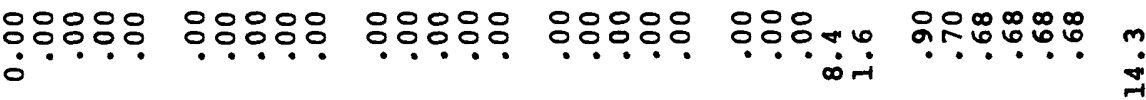

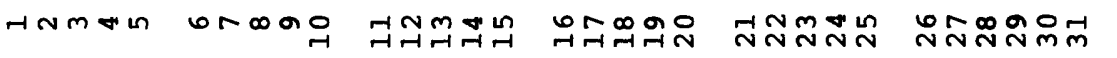

1.




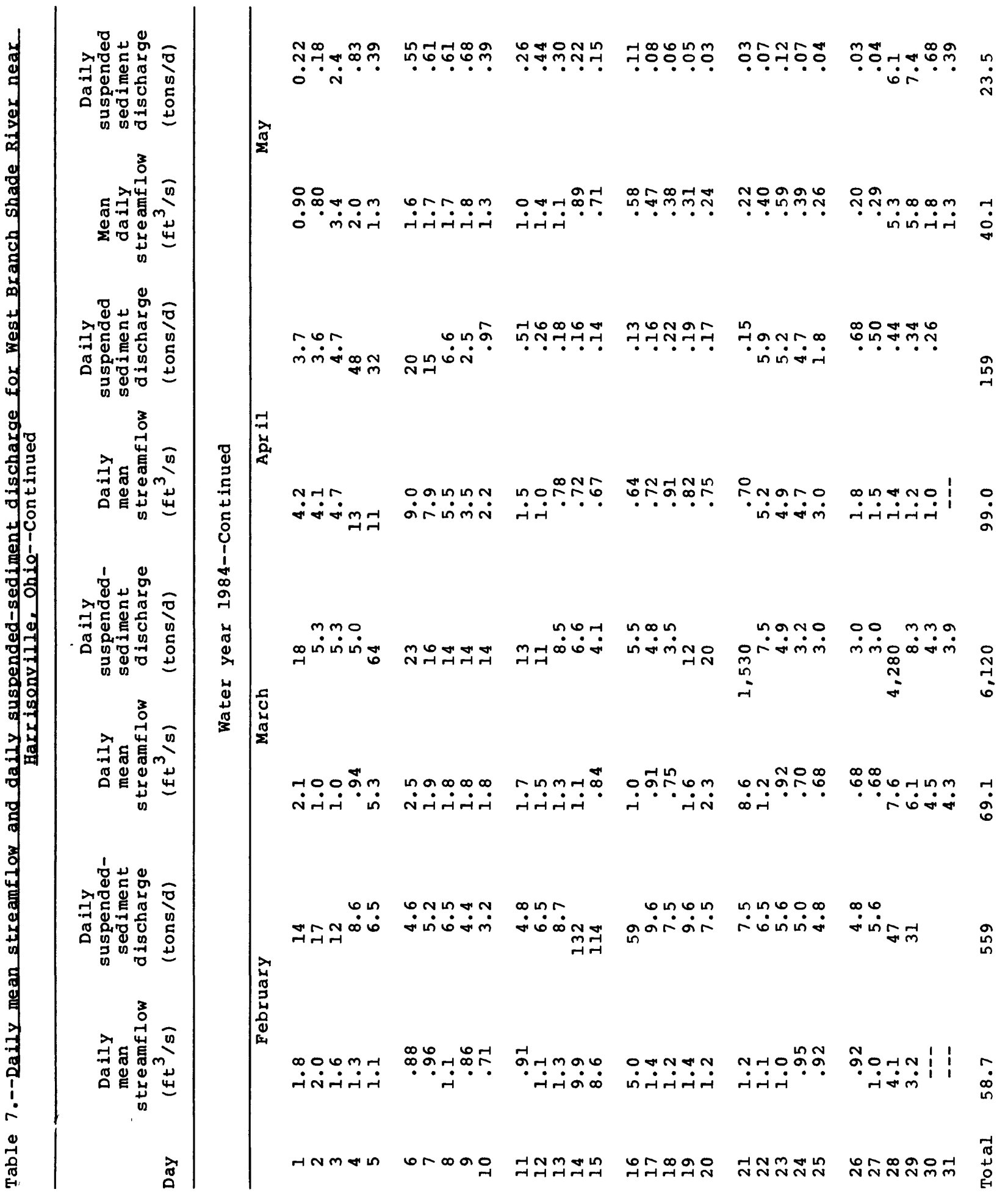




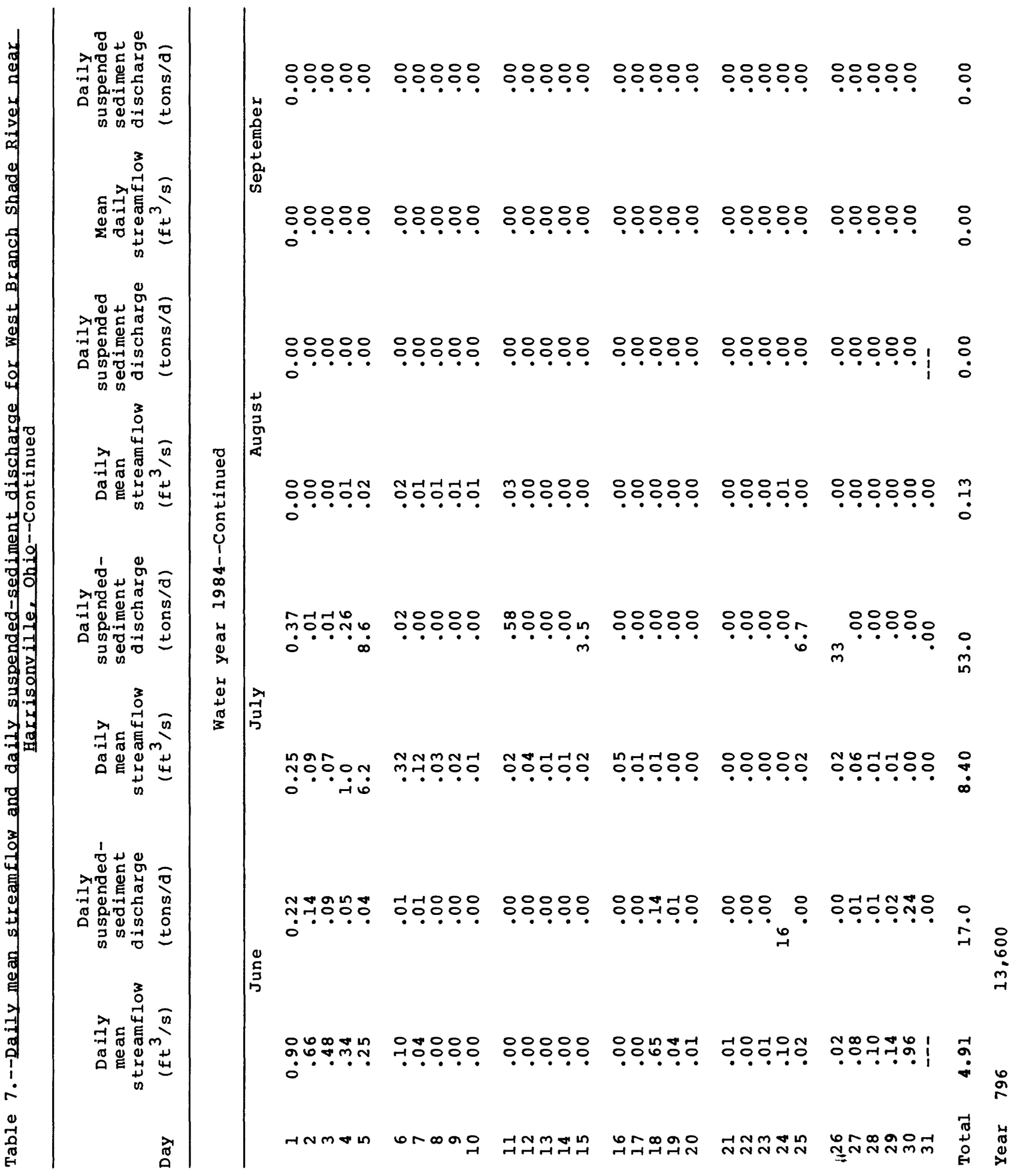




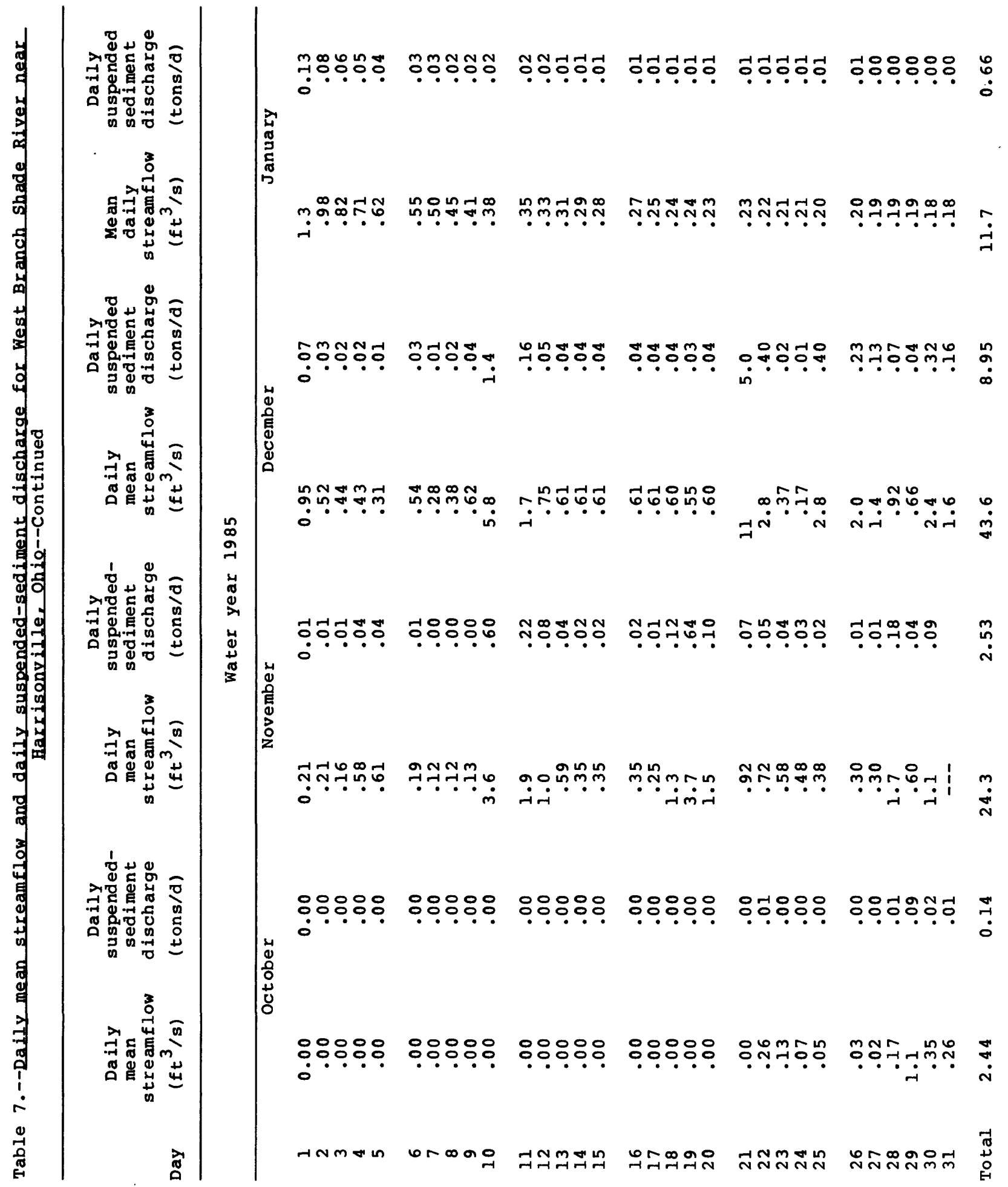




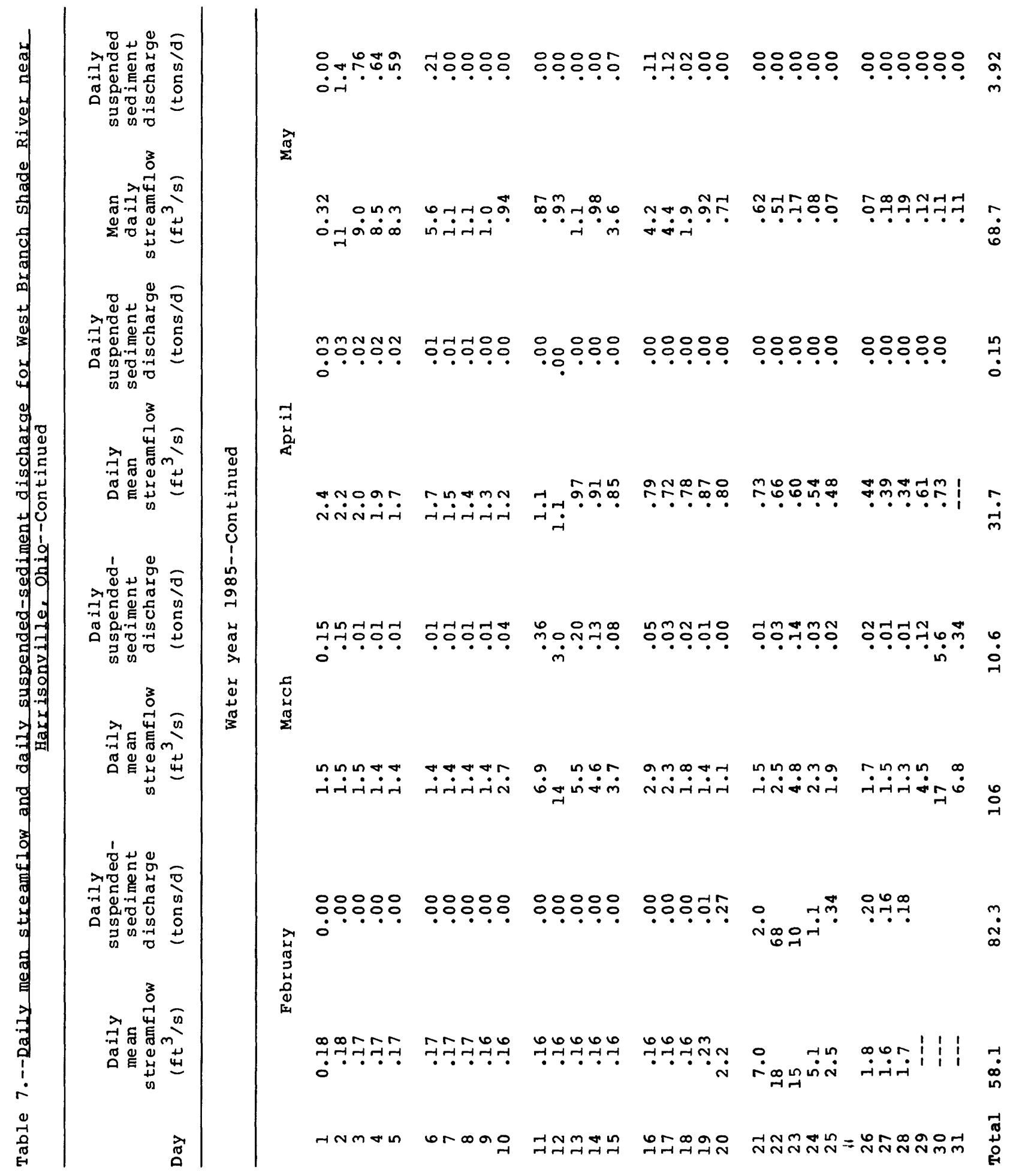




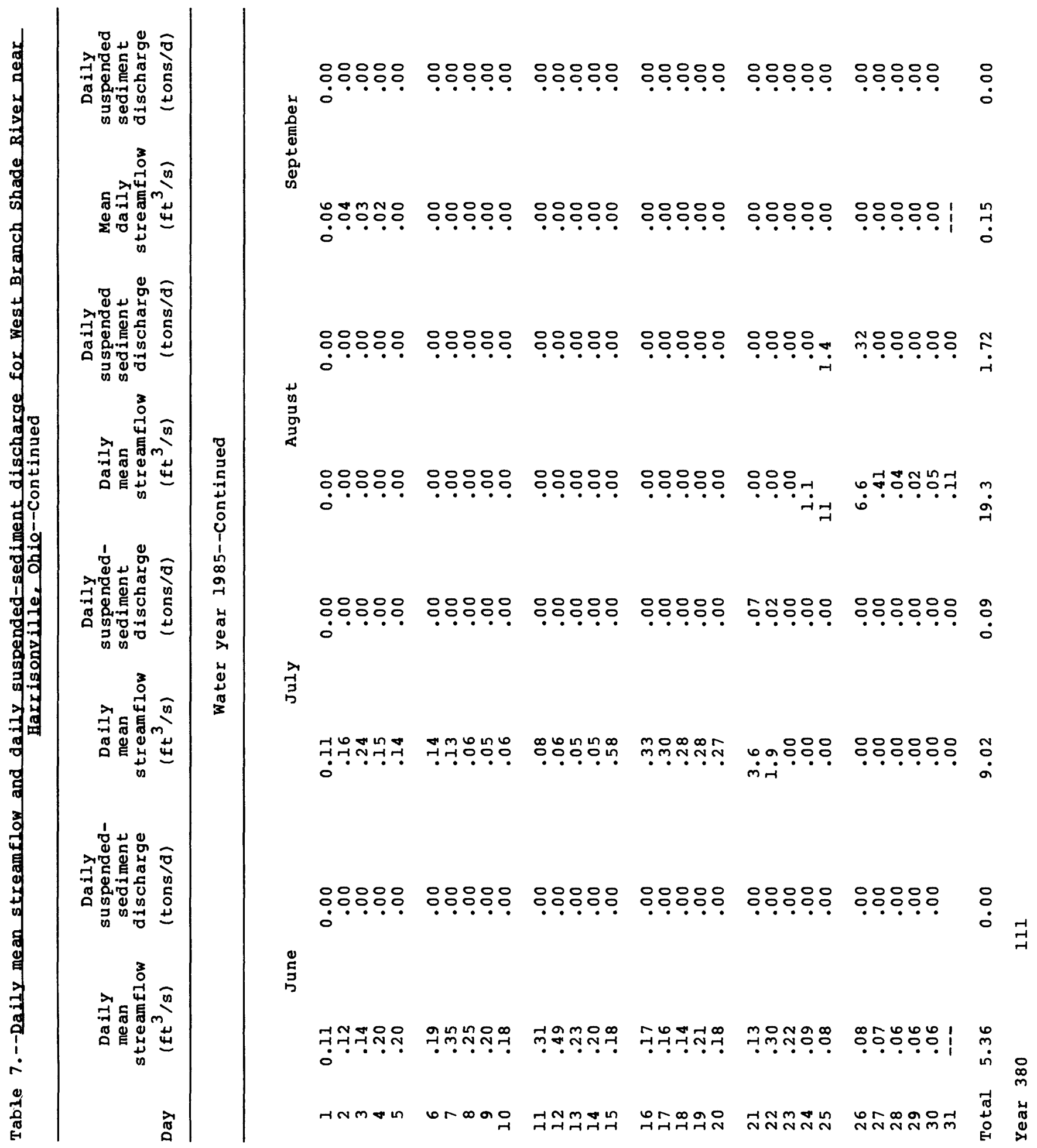

